\title{
التدريب والتطوير في دولة الإمارات العربية التححدة \\ دعامة من دعامات الأمن الوظيفي
}

موسى مصطفى شتحادة

استاذ القانون العام الشارك

كلية القانون - جامعة الشارقة 


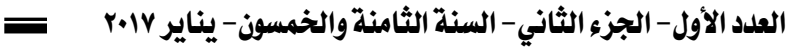

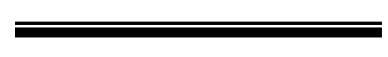




\section{unily}

انصب موضوع هذا البحث على در اسة التدريب و التطوير و التأهيل الـــوظيفي

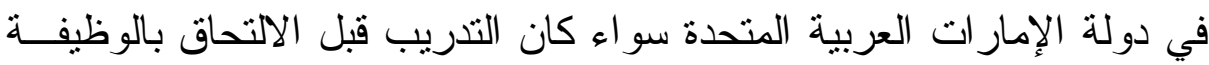

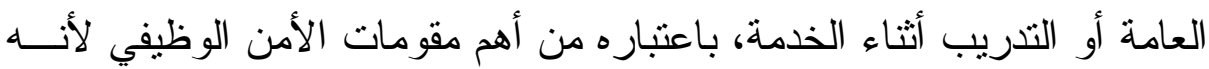

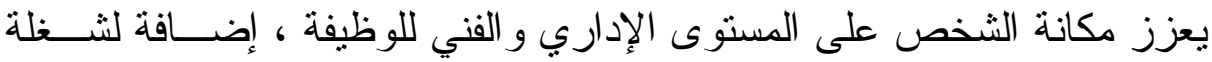

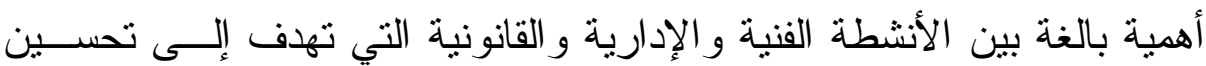

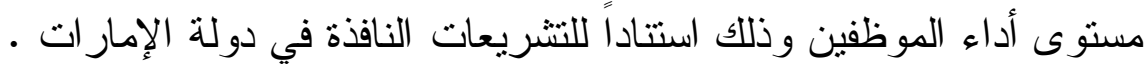

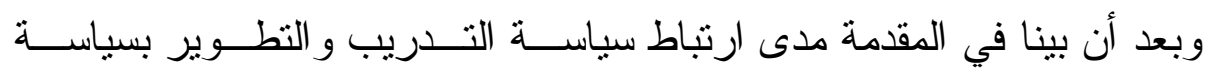
الإصلاح الإداري ومحاولة تعريف الأمن الوظيفي ومقوماته، درسنا السياســـة لئهة

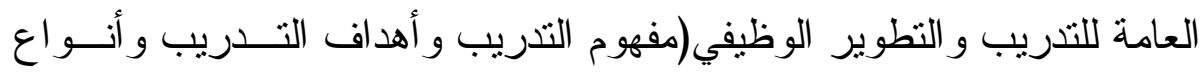
التذريب) ، ثم تتاولنا تحديد وتحليل احتياجات التدريب (استر اتيجيات التدريب)

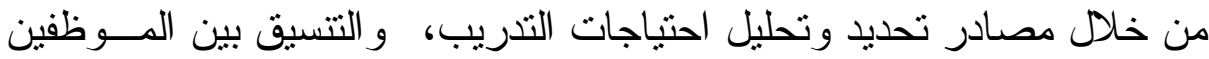

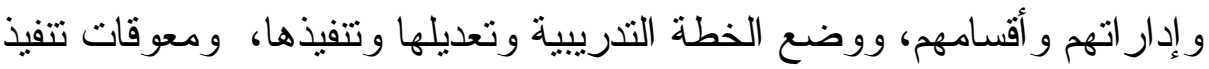

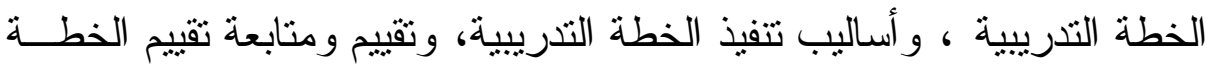

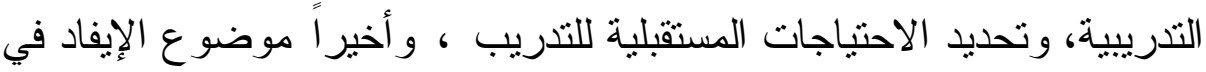

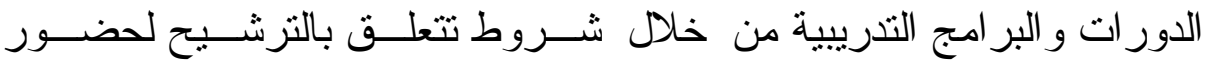

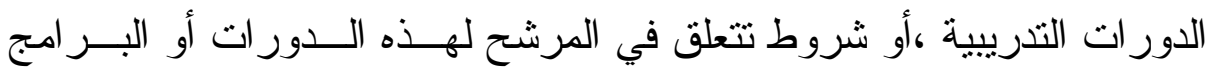

$$
\text { التدريبية أوفي مدة التنريب أوفي }
$$

السلطة المختصة وشروط أخرى نتعلق بحقوق وو اجبات المتدرب .

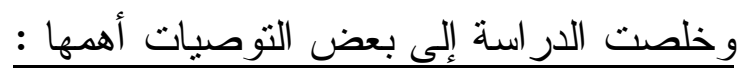

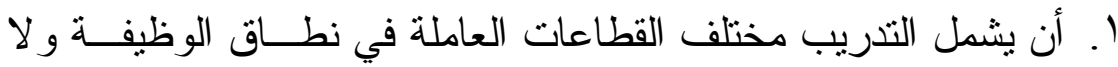

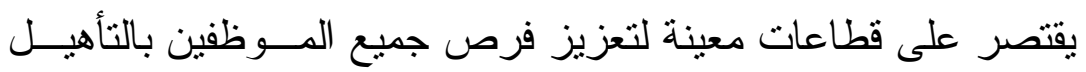

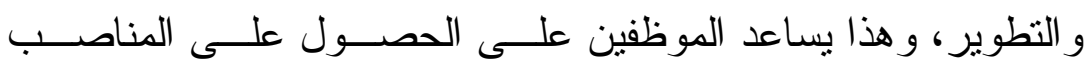

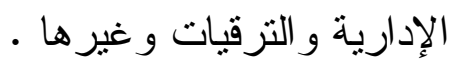

r. أن لا يقتصر التدريب في داخل الدولة وإن ما يجب على على الدولة تعزيز

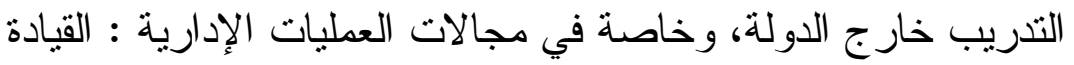
و التتظيم و التخطيط و التتسيق وحل المشكلات وخلات. 


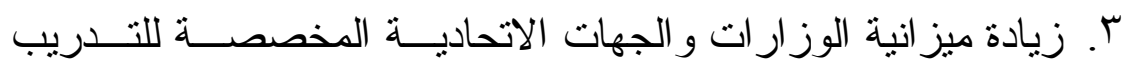
و التطوير و التأهيل في طاق الوظيفة لزيادة قدر ات ت الموظفين العــامين خاصة في دولة ناهضة كدولة الإمار ات العربية المتحدة.

\section{مقدمبة عامة}

\section{ارتباط سياسة التدريب والتطوير بسياسة الإصلاح الإداري}

لقد ارتبط مفهوم الوظيفة العامة ارتباطاً وثثيقاً بتطور مفهوم الدولــة الحديثــة

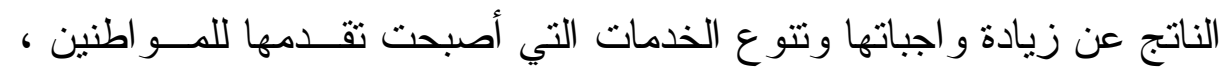
وخاصة بعد الحرب الكونية الثانية وبروز الأفكار الاشــتر اكية و الاجتماعيــة و الاقتصادية وسياسة التأميم و الخصخصة التي ألقت على عانق الدولة مهمــات جديدة ومتعددة بعد تحول دور ها من الدولة الحارسة التي تقتصر مهمتها علـىى الأمن الداخلي و القضاء إلى الدولة الحديثة المتدخلة في جميع مناحي ومناشــــ الحياة السياسية و الاقتصادية و الاجتماعية و الثقافية و التتظيمية و البيئية و الفنية ،

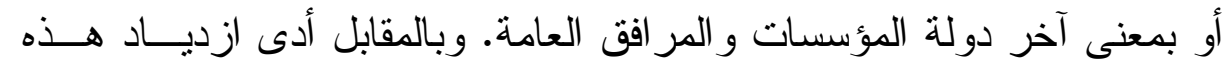
الخدمات و المجالات إلى زيادة في عدد الموظفين القائمين علــى إداه ونشـــيل هذه المر افق و المؤسسات العامة. و أصبحت هذه الفئة من المــوظفين -و التـي تشكل شريحة هامة في المجتمع لها خصائصها ونظامها القانوني الخاص بهــا

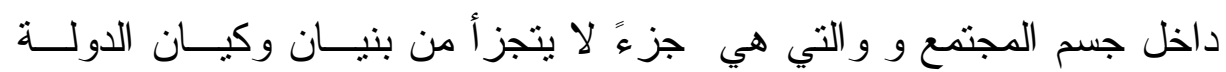

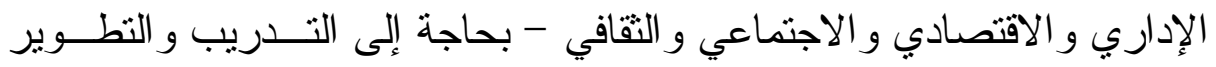

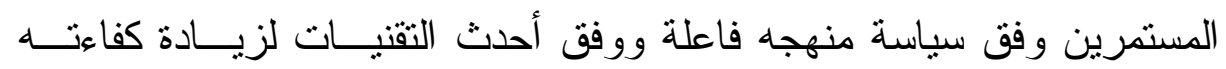
وتحسين أدائه .

وتعمل الإدار ات جاهدة على تحقيق أهدافها بكفاءة وفاعلية ، و لا بتأتي ذلك إلا من خلال تبني الدولة سياسة الإصلاح الإداري، خاصة و أن الإصلاح الإداري

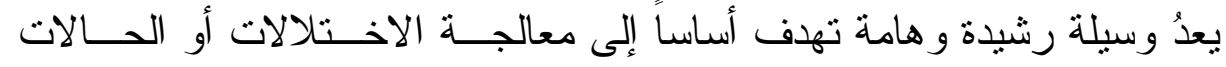

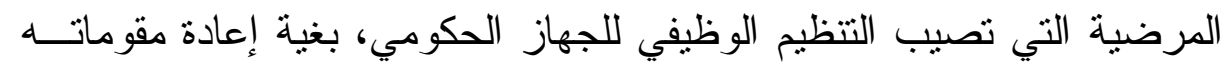

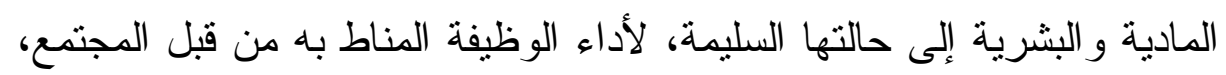
وبهدف إحداث تغيير ات أساسية و إيجابية فـي الســلوك و الــنظم و العلاقـات

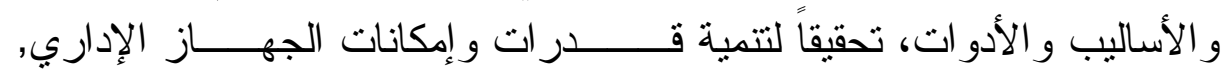
بما يؤهن له درجة عالية من الكفاءة و الفعالية في إنجاز أهدافــه أو تحسـين 
و احد أو أكثر من عناصره الرئيسة كالهياكل التنظيمية أو شؤون المـــوظفين أو العمليات الإدارية. ومن هنا فان المدخل إلى عملية الإصلاح الإداري وتتمية المــــارد البثـــــية

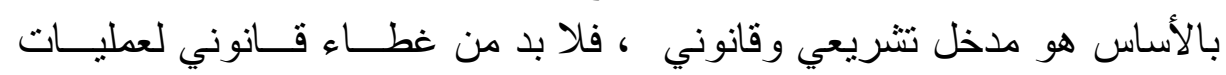

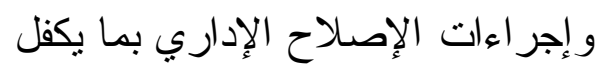

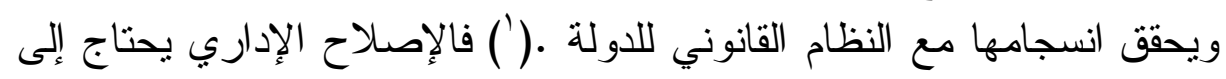

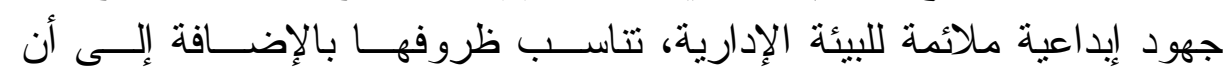

(1)- أن أول قانون للوظيفة العامة (الخدمة المدنية الاتحادية) بدولة الإمارات العربية

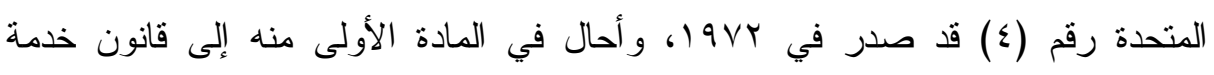

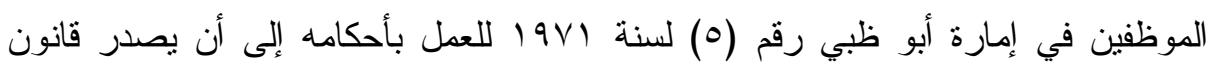

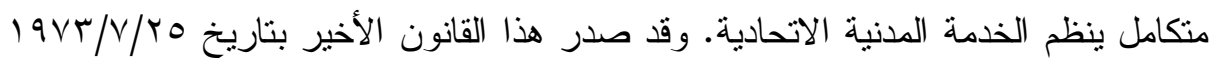

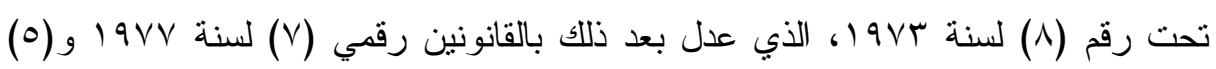

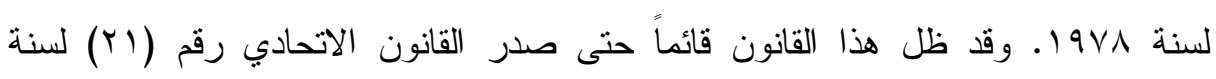

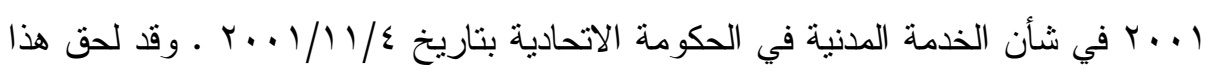

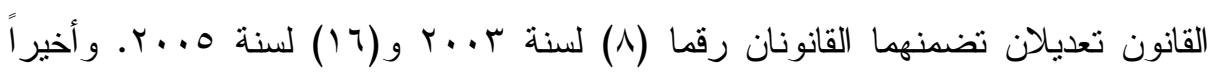

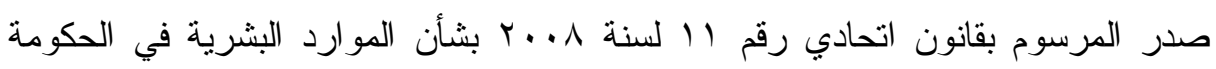

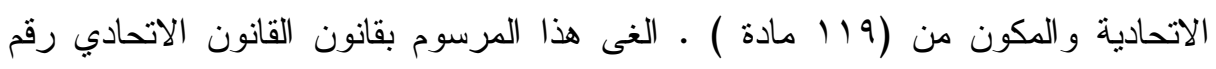

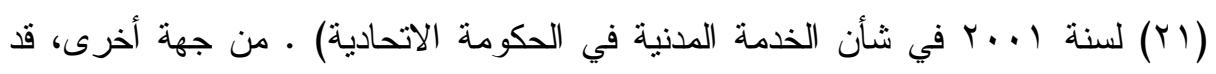

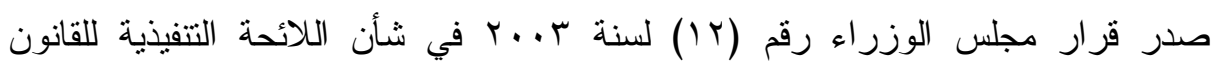

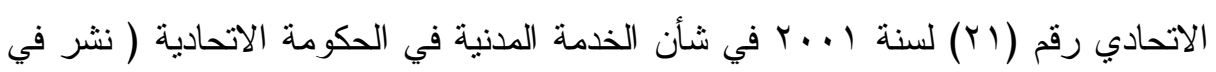

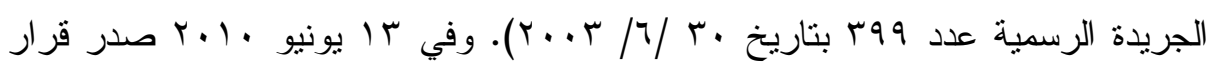

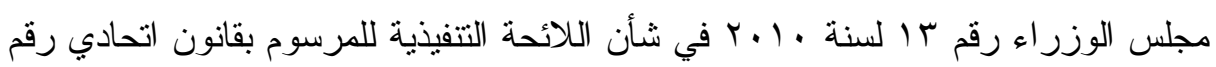

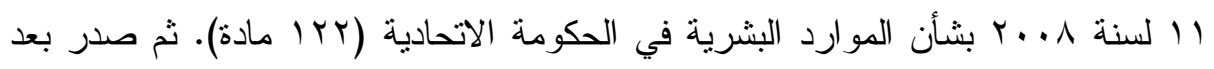

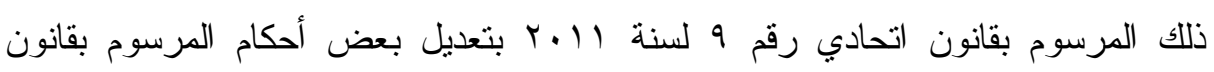

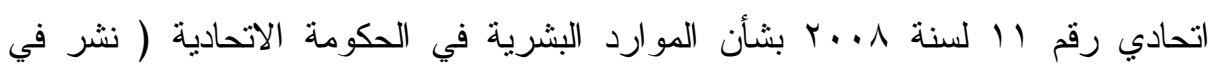

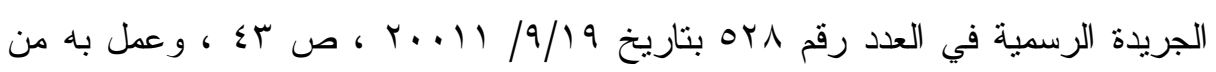

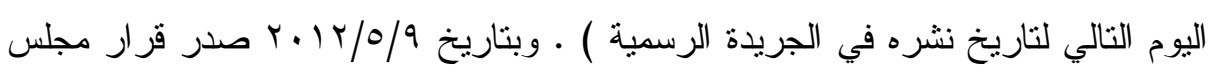

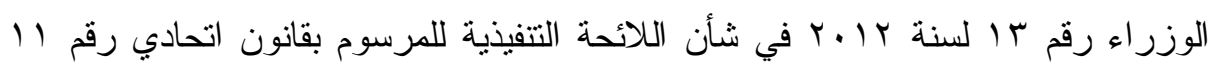


الإصلاح الإداري ليس عملية وقتية أو زمانية، ولكنه منهج عملـي وفكــري

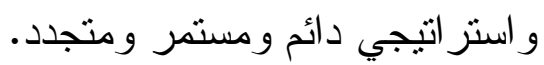

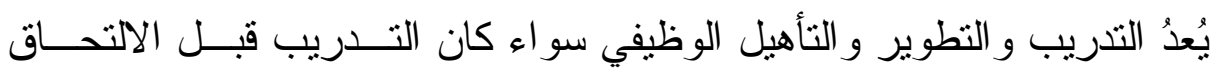
بالوظيفة العامة أو التدريب أثتاء الخدمة ، من أهم مقومات الأمن الوظيفي لوني لأنداء

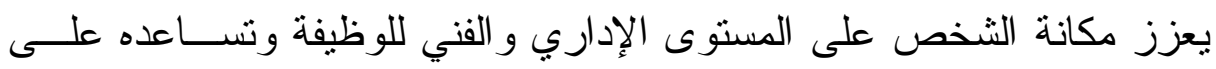

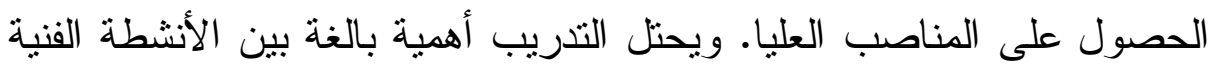

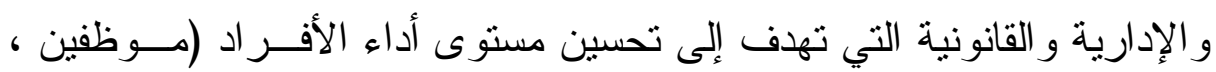

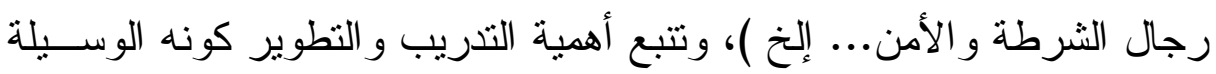

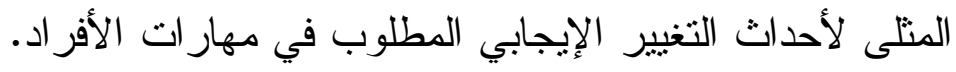

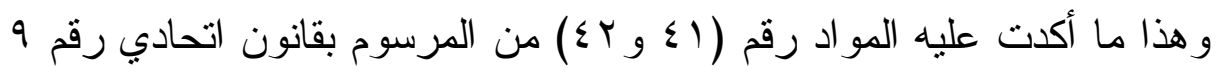

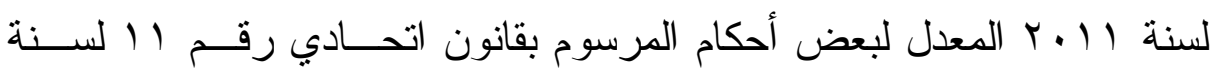

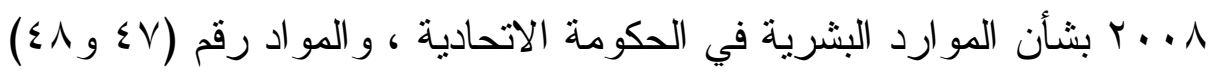

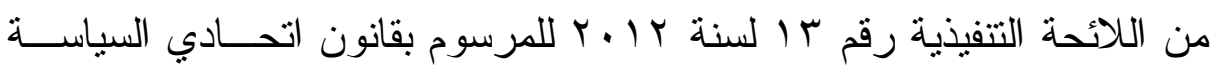

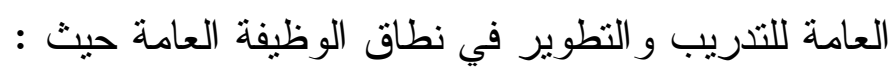

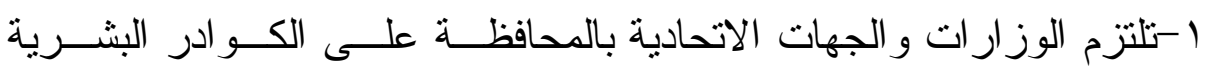

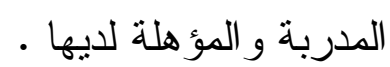

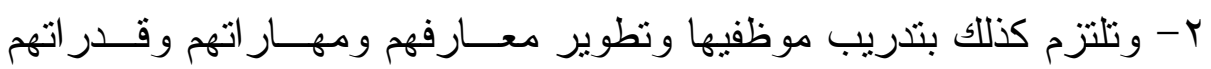

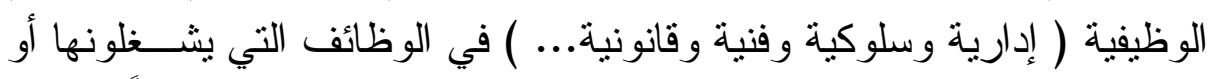

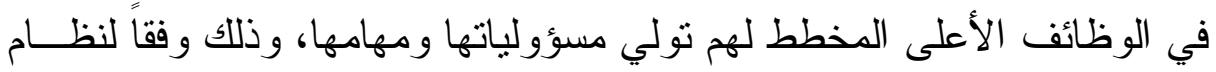

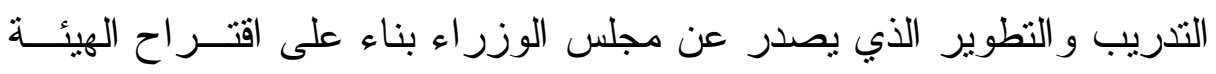

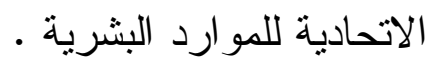
r- كما وتلتزم أيضاً بوضع وتتفيذ خطط سنوية لتدريب وتأهيـلـ المــوظفين

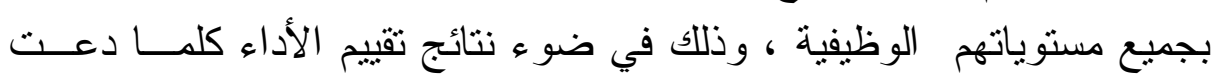

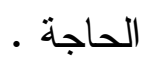

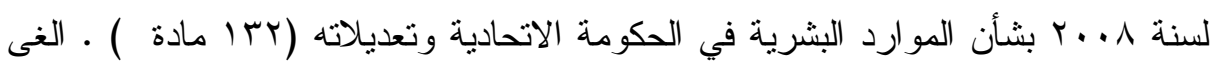

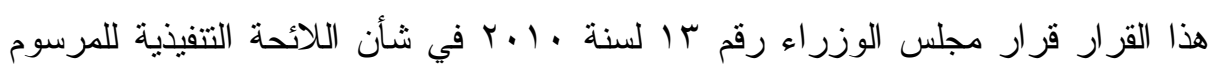

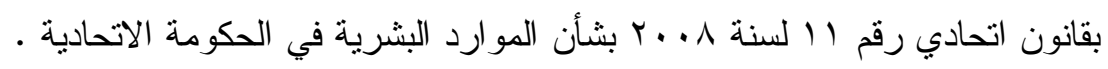




\section{(1) محاولة لتعريف مصطلح "الأمن الوظيفي"}

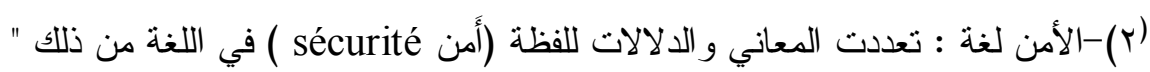

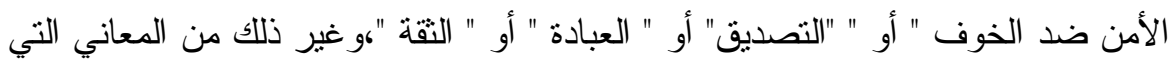

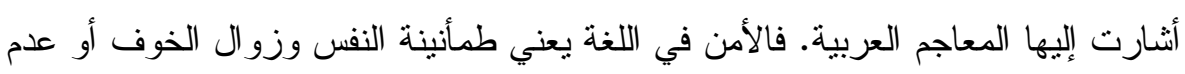

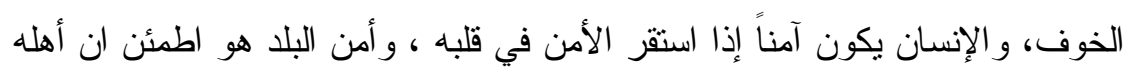

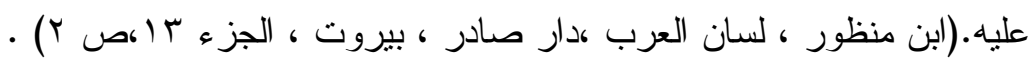

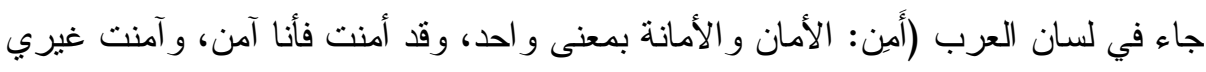

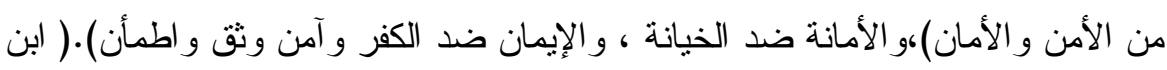

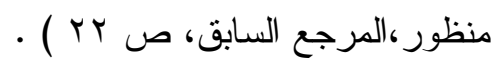

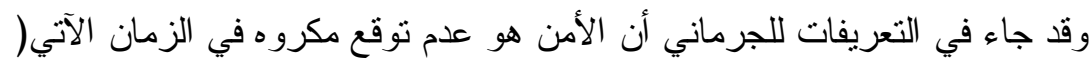

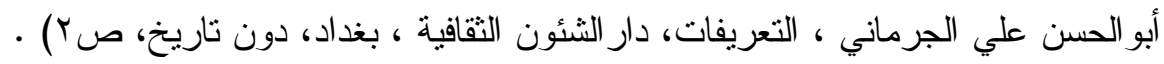

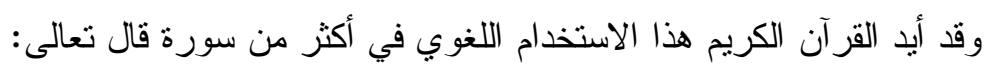

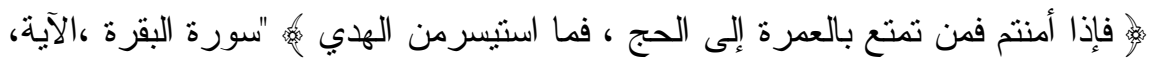

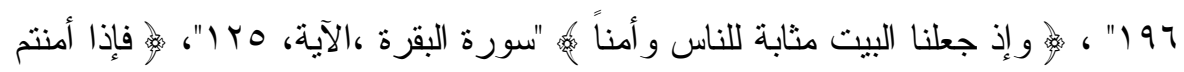

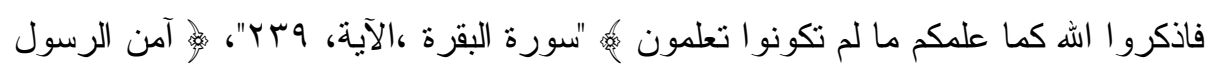

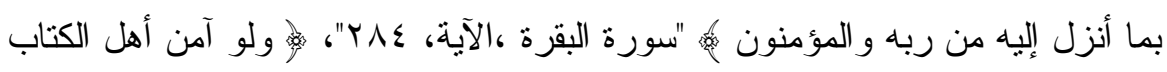

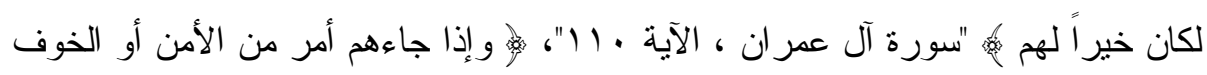

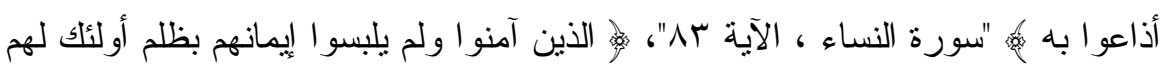

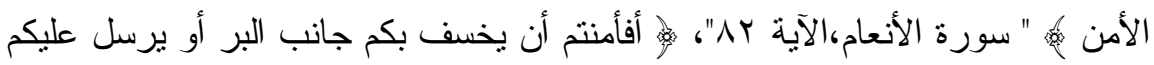

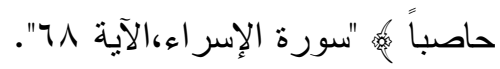

أما في الاصطلاح فيعرف الأمن بأنه " إحساس الفرد و الجماعة البشرية بإنباع دو افعها

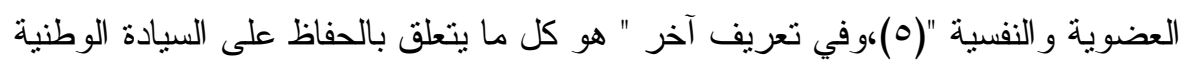

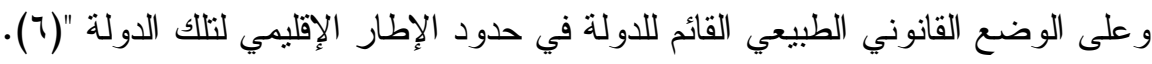

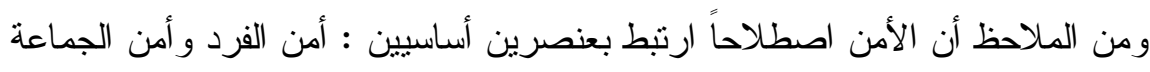

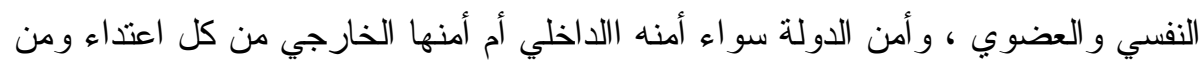
الفتن و الحروب الخارجية أو الداخلية.

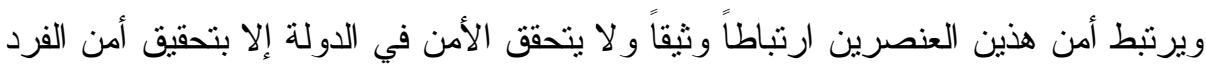
و الجماعة وأمن الدولة ، وأي خلل يعتري أحدها سيؤثر سلباً على الآخر . 
مما لا شك فيه أن للعلاقات الإنسانية و المعنوية في الوظيفة العامة - باعتبار ها

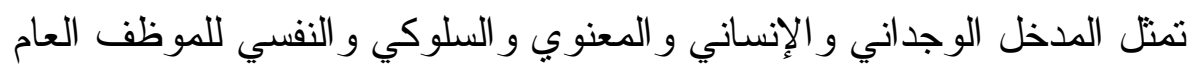

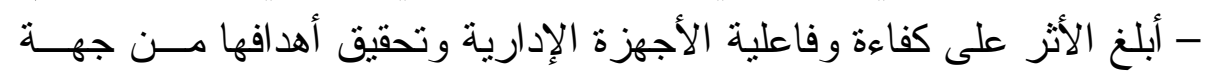

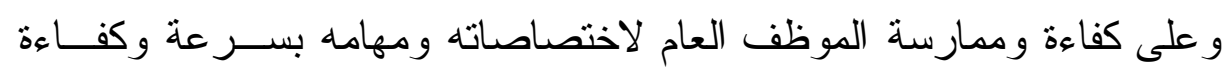

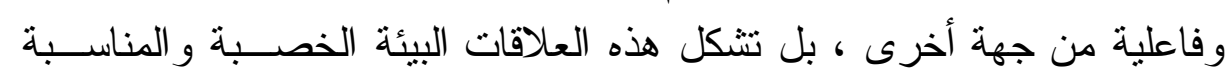

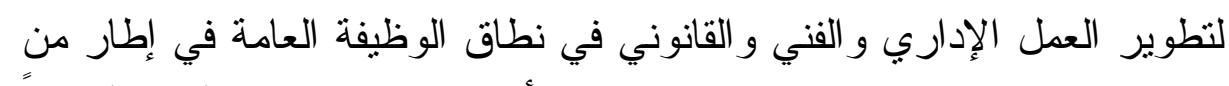

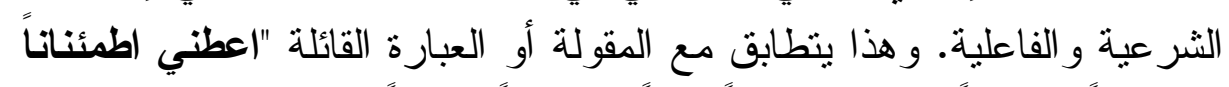

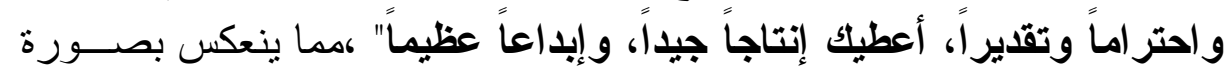

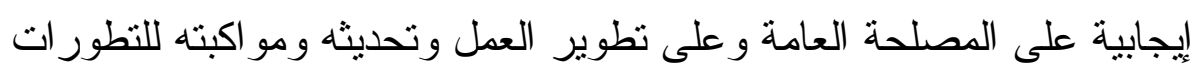
الفنية و التقنية في عالم التكنولوجيا و الاتصالات و الحاسوبة...

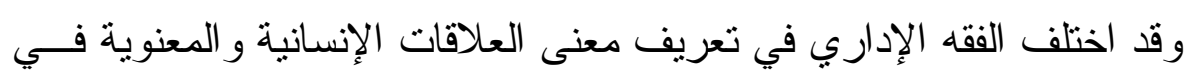

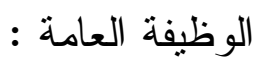

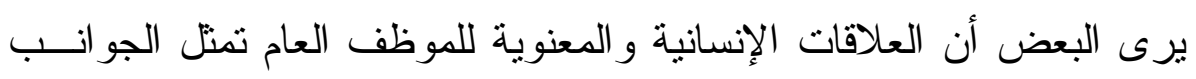

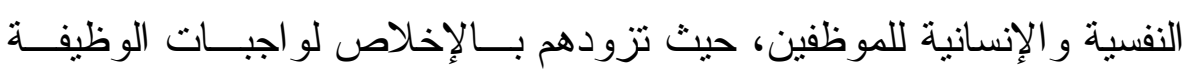

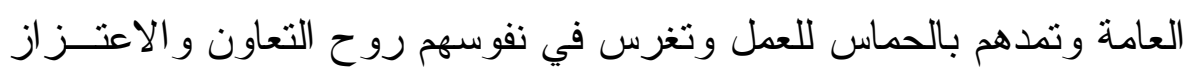

و لا يبتعد مفهوم الأمن وظيفة عن المعنى اللغوي و الاصطلاحي، فالأمن و الأمن العام يعني

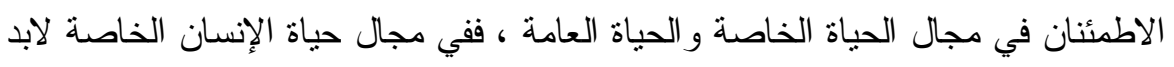

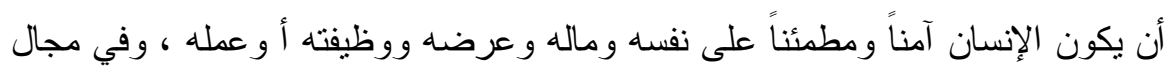

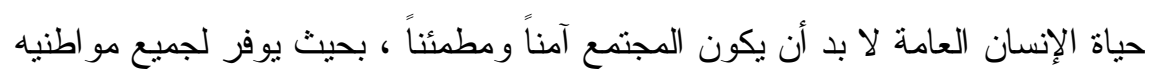

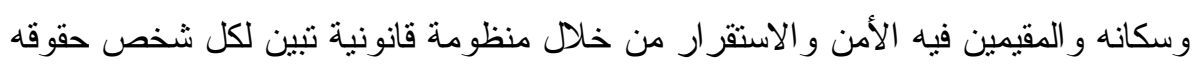
وو اجباته. فالأمن قو ام الحياة وسبب ازدهار ها وحضارتها وتقدمها ، ولهذا كان الأمن قاعدة كل قو اعد

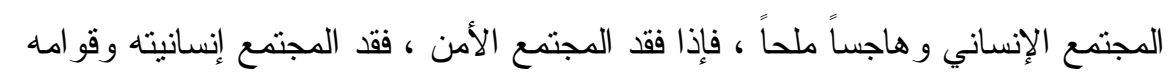

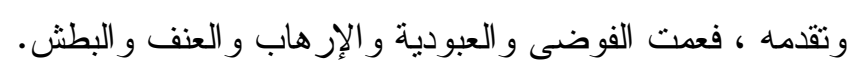

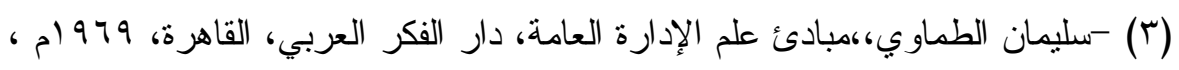
ص ع. - -حسن عادل، وفوزي عبد المنعم،الإدارة العامة، منشأة المعارف،الإسكندرية،

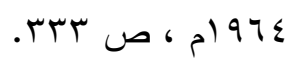




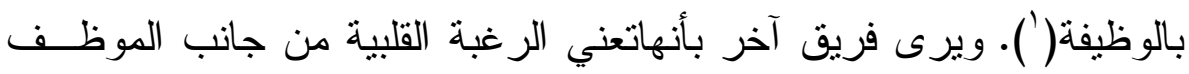

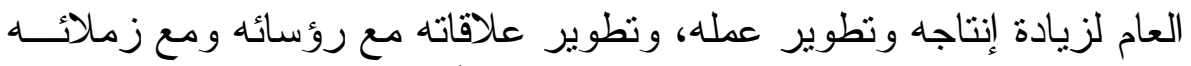

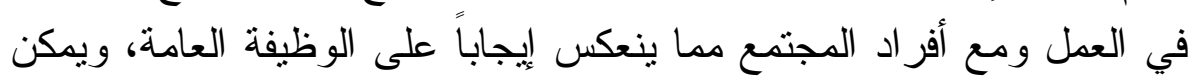

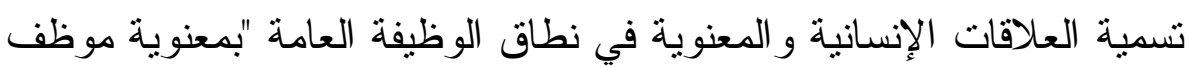

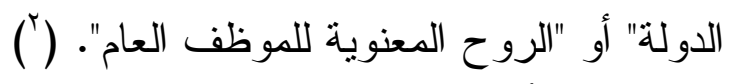

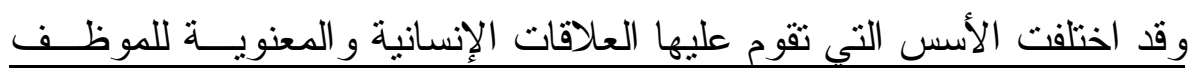

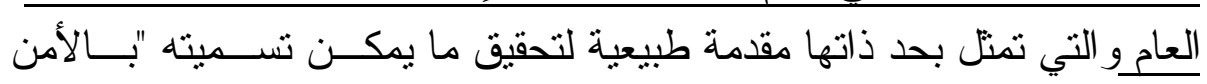
الوظيفي "La sécurité de L'emploi وتختلف هذه الأسس عند فقهاء الإدارة والقانون الإداري تبعاً لاختلاف النظرة إلى طبيعة هذه العلاقات.

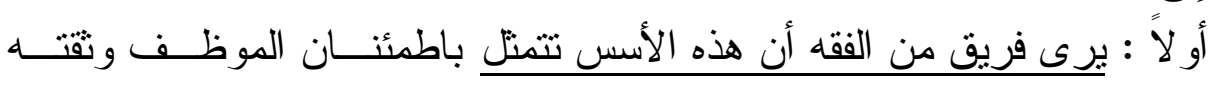

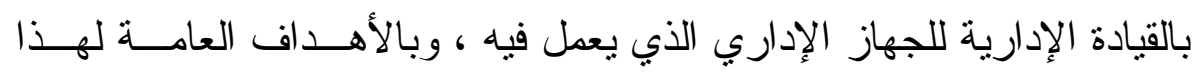

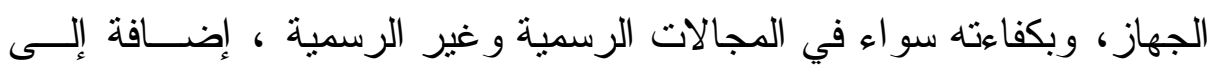

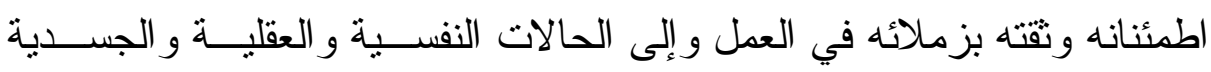

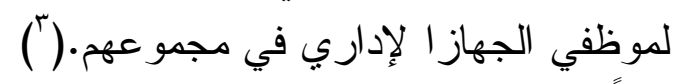

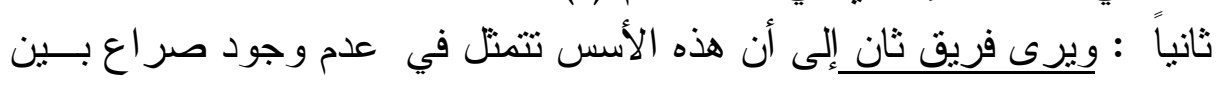

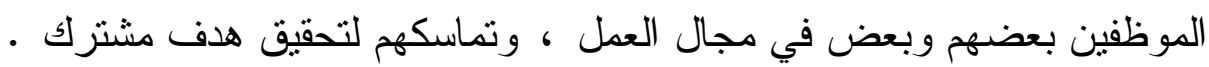

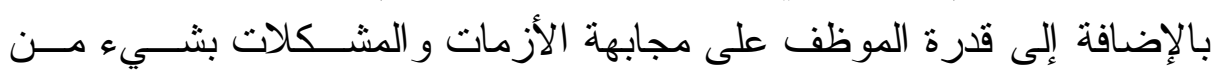

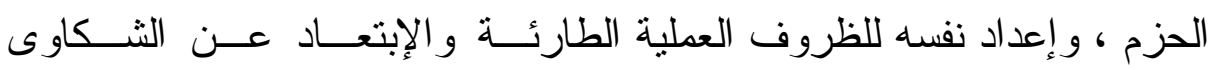

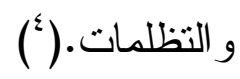

(5)-MOSHER William, KINGSLEY J. et STAHL, public personnel Administration, New York, Herper and Brothers, 1950 p. 286 (7) -حسن عادل، وفوزي عبدالمنعم، الإدارة العامة،مرجع سبق ذكره ،ص سبr وما

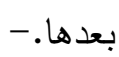

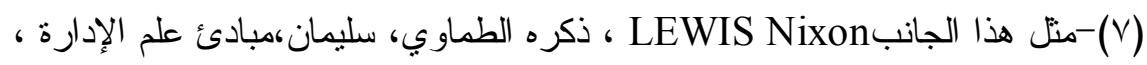

$$
\text { مرجع سبق ذكره ، ص ه هـ } 7 \text { وما بعدها. }
$$

(8)-CAIDEN Gerald E., The Dynamics of public administration, New York, Holt Rinehart and Winston, INC, 1971, p. 234 


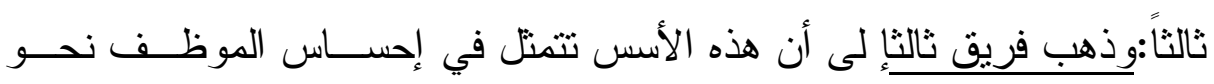

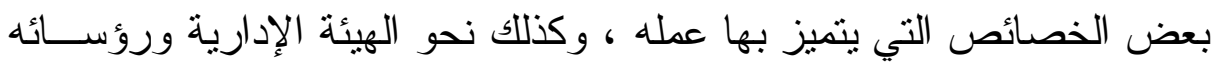

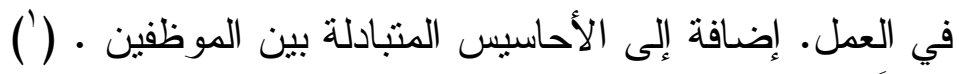
رابعاً:وذهب فريق رابع إلى أن هذه الأسس تتمثل في نوعية الثقافة التي ورثنها

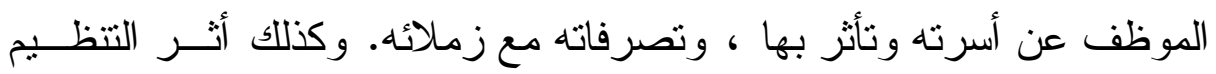

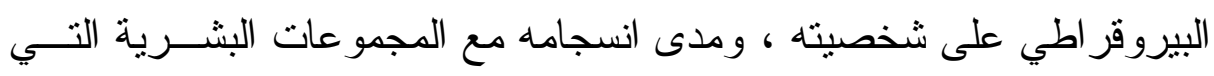

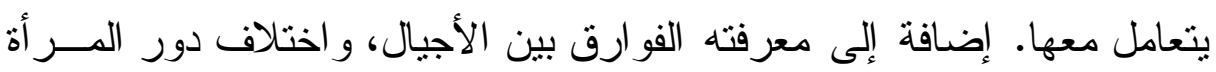

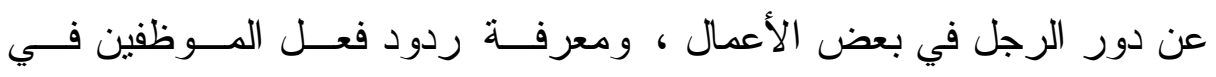

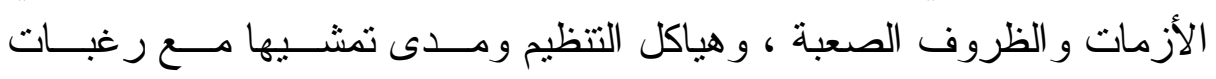

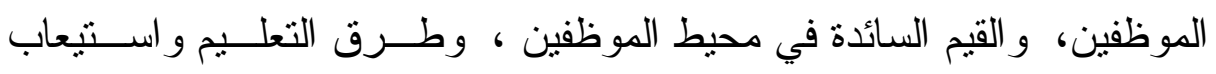

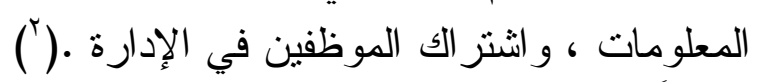

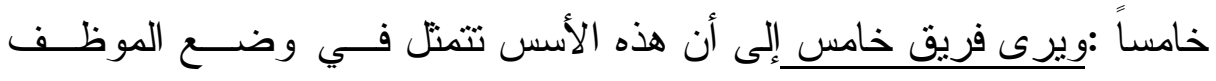

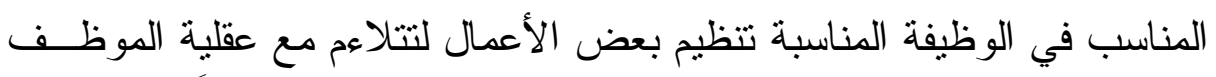

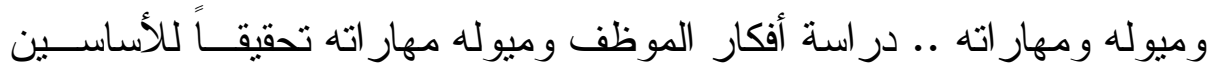

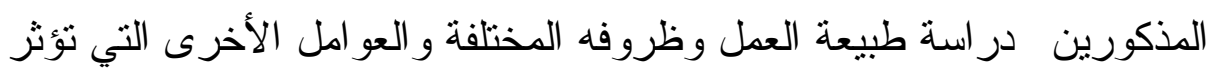

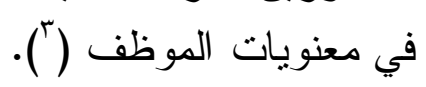
ومهما يكن فإننا نرى أن العلاقات الإنسانية و المعنوية في نطاق الوظيفة العامة

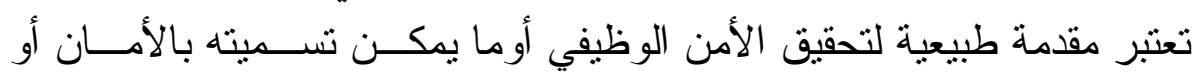

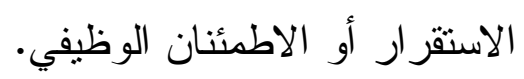

(9)-ERBERT H. HICKS and GRAY GHLLETT, organization, Théory and Behavior,

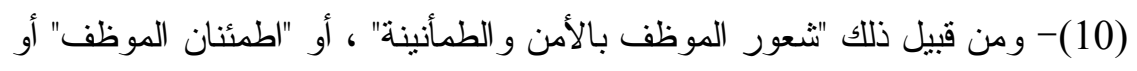

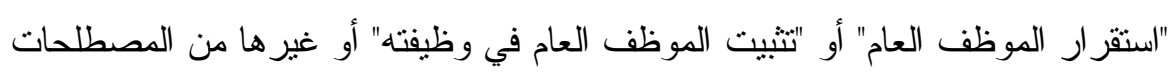

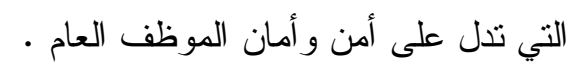

(11)-CARTON Jean - Paul, Essai de Typologie de L'insuffisance professionnelle, Actualité Juridique, Droit Administratif(AJDA), février 2003 p. 265. 
و على الرغم من عدم شيوع مصطلح الأمن الوظلفي في فقه القـانون الإداري

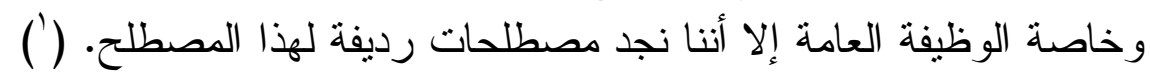

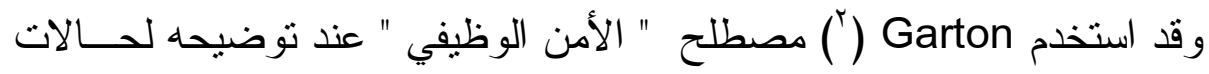

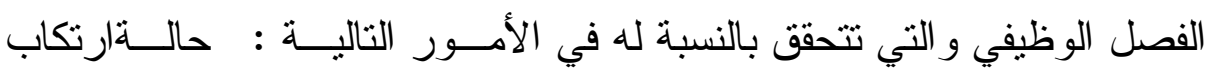

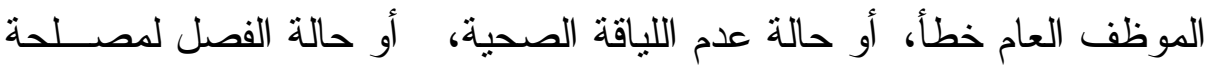
المرفق العام، أوحالة عدم الكفاية المهنية.

وبينGarton هأن Garton هذه الحالات تظهر بوضوح حسية نسية قدسية الأمسنـ

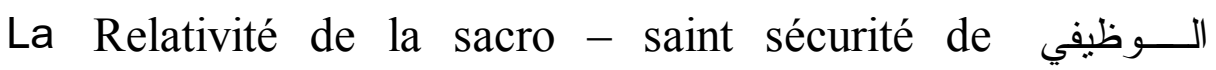

(").l'emploi و هكذا فإن الفقه لم يعرف "الأمن الوظيفي "و إنما ربطه بمفهوم المخالفة بحالات

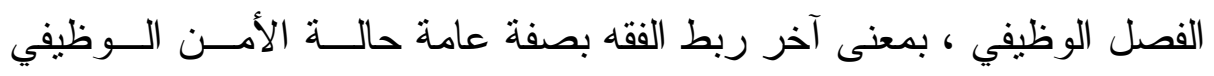

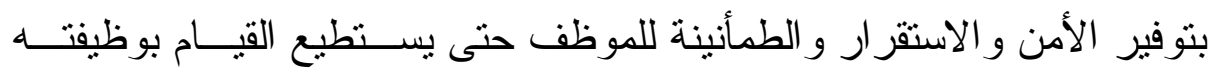
بصورة فعالة ومثمرة.

وفي ضوء ماسبق يمكن تعريف الأمن الوظيفي بأنه " توفير الأمن و الطمأنينـــة

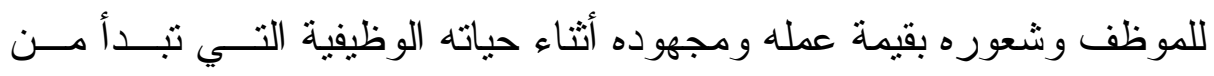

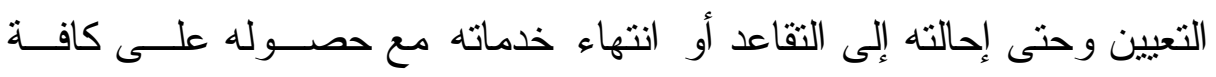
استحقاقاته و امتياز اته ".

\section{الاقتومات الأساسية للأمن الوظيفي}

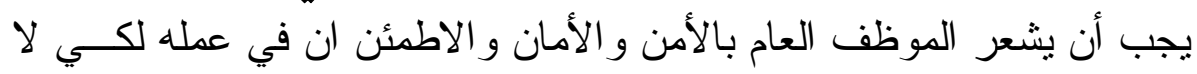

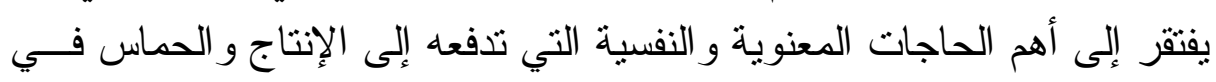

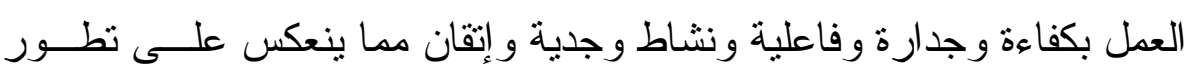

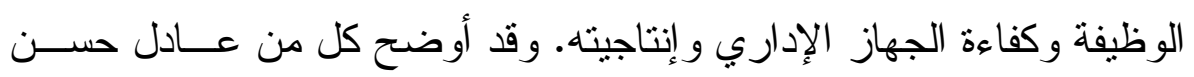

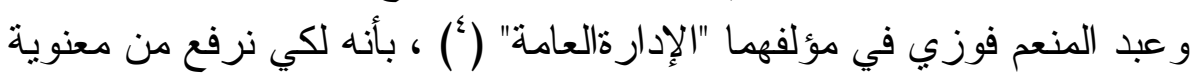

(12)- Ibid . المرجع السابق.

(T (1)- حسن، عادل وفوزي، عبدالمنعم، مرجع سبق ذكره، ص ع بس. 
الفرد لا بد من أن نهيئ له الظروف و الثروط التي يطلبها في العمـلـل الــذي لــي

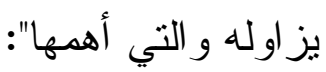

1 - أن تهيأ لكل فرد فرصة التعبير عن نفسه في عمله ، وفرصة أداء هذا العمل بدرجة من الإتقان تجعله يعتز بإنتاجه.

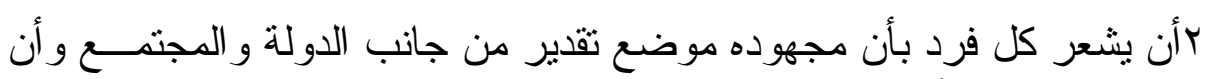

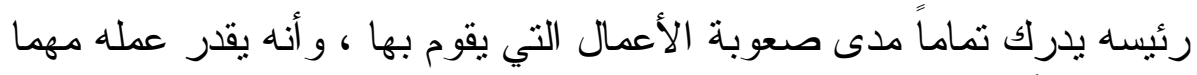
كان بسيطاً. ب-أن يشعر كل فرد بمدى أهمية الدور الذي يلعبه فــي نشــاط المصــلحة أو

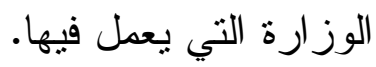

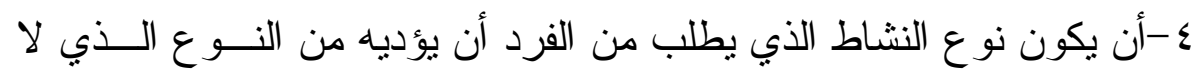
ينتقص من احتر امه لنفسه أو يهين كر امته. ه-أن يتحرر الفرد من القلق النفساني بسبب حاضره أفر و مستقبله.

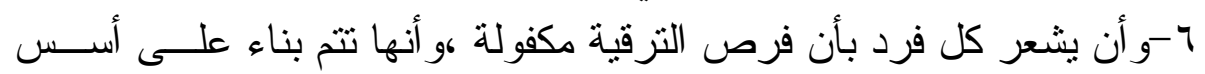

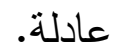
V-أن يهيئ له محيط عمل يتميز بالهدو و و الصداقة و التعاون و الإخاء.

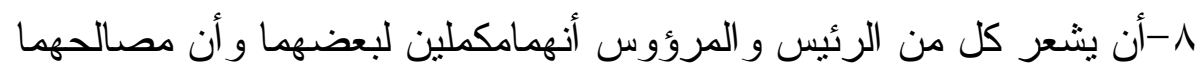

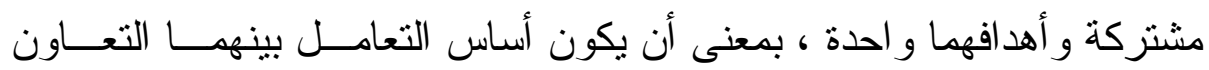
وليس الأمر و النهي وتصيد الأخطاء لكل منهما". وقد أوضحت العديد من الدر اسات و الأبحاث على وجود علد علاقة إيجابية و اضحة وفعالة بين الرضا الوظيفي وبين كفاءة وفاعلية الإنتاج للموظف.(')

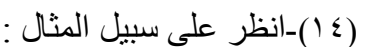

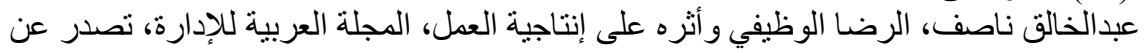

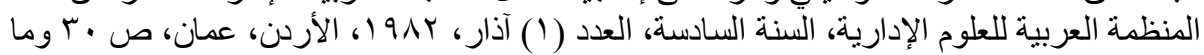

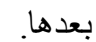
LIKERT Rensis, New Patterns of manegement - New York, MC Graw Hill .Book Co., 1961, ch. 6 p. 118 (10) - حسن، عادل وفوزي، عدالمنعم، الإدارة العامة، مرجع سبق ذكره. 


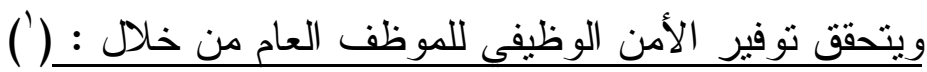

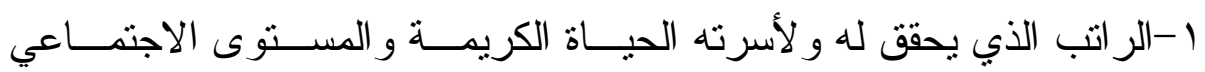
المناسب.

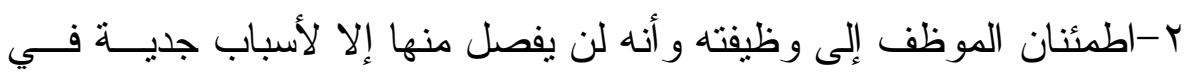

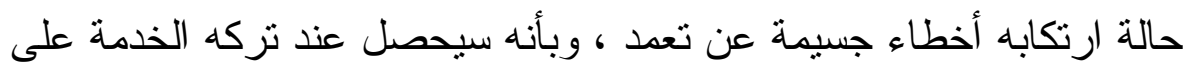

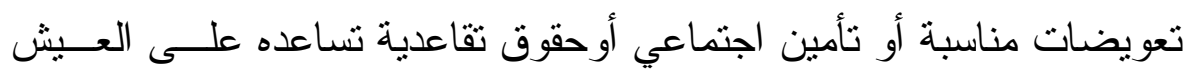
الكريم وتحميه من مشكلات الدهر و العجز و الشيخوخة.

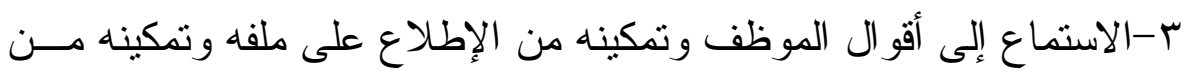
الاففاع عن نفسه خاصة في المسائل التأديبية.

ع -توفير فرص الترقية للموظف بعدالة مطلقة ومنحه الإجاز ات الملائمة. ه-معاملة الموظف باحتر ام وكياسة وتقدير من جانب رؤسائه و إشعاره بمكانته وبشخصيته المستقلة. ؟-ثقدير الجهد و التفوق أو التميز : يجب على الرؤساء الإداربين تقدير جهــود

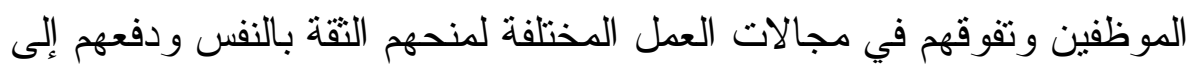
المزيد من بذل الجهد و العطاء و الابتكار و إتقان العمل. ويكون ذلك عن طريق تشجيعهم المستمر بالوسائل الملائمة ومن بينها شهادات

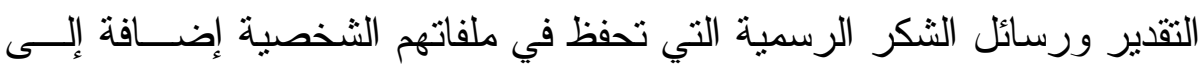

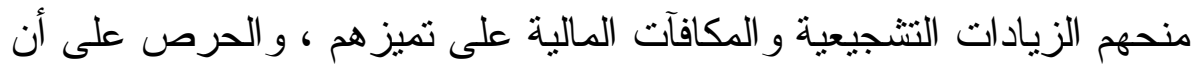

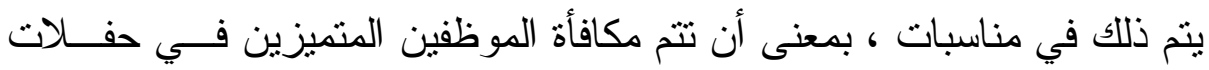

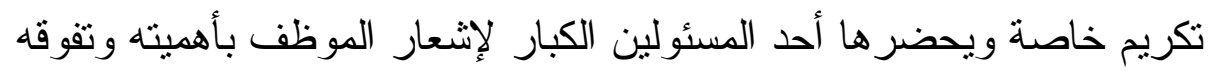
و إبداعه.

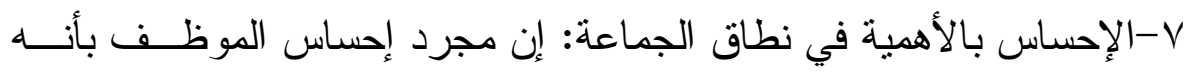

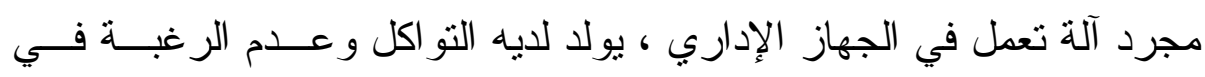

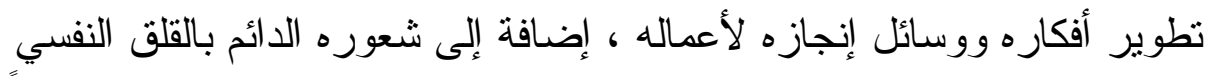

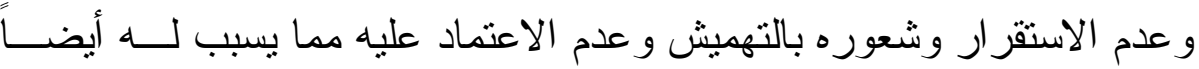

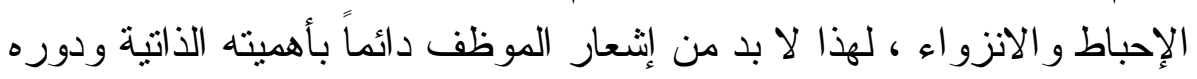
في تحقيق أهداف الجهاز الإداري الذي لإني لإندل فيه. 


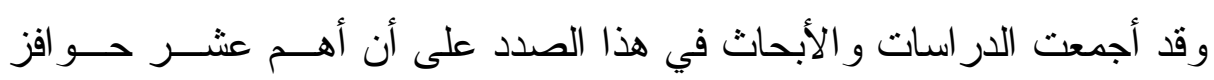

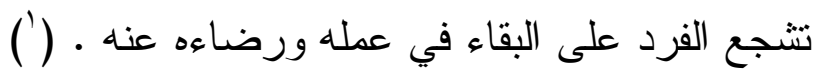
ندرس التدريب و التطوير في نطاق الوظيفة العامة في دولة الإمار ات العربيـــة المتحدة في ثلاثة مباحث : لئن

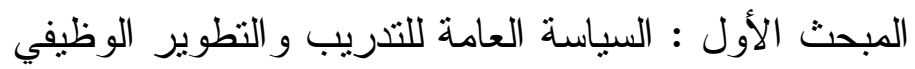
المبحث الثاني: تحديد وتحليل احتياجات التدريب (استر اتيجيات التدريب) المبحث الثالث : الإيفاد في الدورات و البراني امج التدريبية

\section{المبمث الأول}

\section{السياسة العامة للتدريب والتطويز الوظيفي ( الافهوم والأهداف والأنواع )}

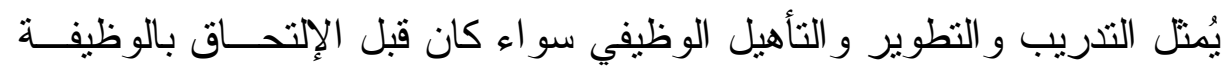

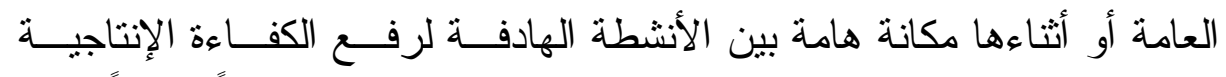

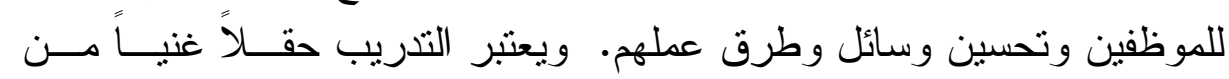

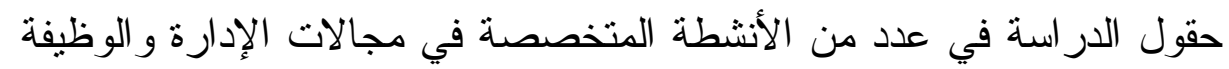

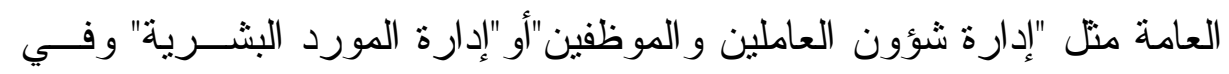

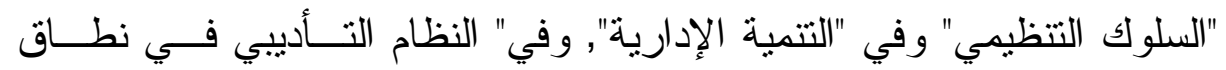
الوظيفة العامة", وفي "حقوق وو اجبات الموظف العام".... وقد أصبحت وظيفة أو مهمة التدريب مهنة متخصصة ولهي لها أفر ادها وهم غالبــاً

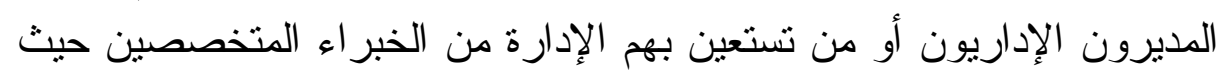
يلعبون دور المخططين للبر امج التدريبية وتتفيذها وتقوين لإدها.

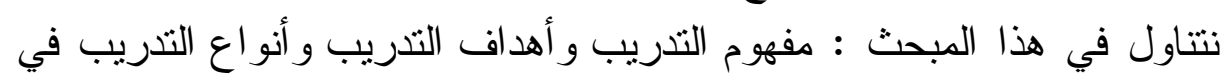

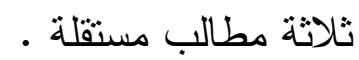

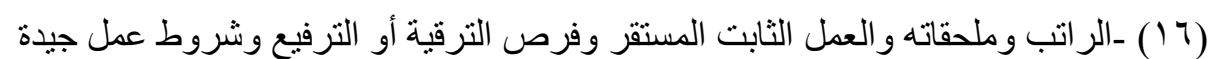

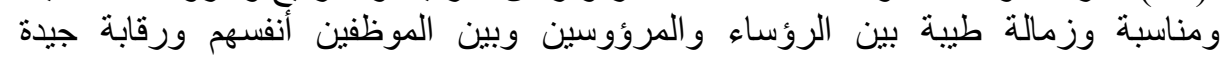

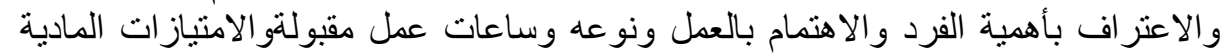
و العينية والمعنوية . 


\section{الإطب الأول}

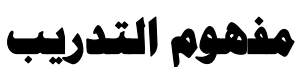

تعددت التعريفات التي قيلت في التدريب الإداري، إلا أنها كلها تسبر في نسق

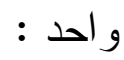

يعرف الدكتور بر عي التدريب بأنه "عملية هدفها إكساب المعارف و الخبــرات

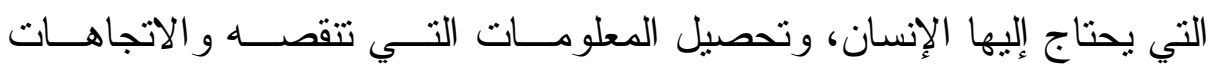

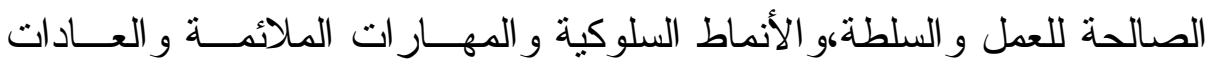

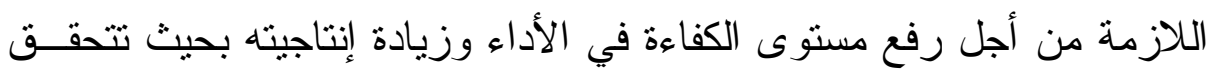
فيه الشروط المطلوبة لإتقان العمل وظهور فاعليته مع السرعة و الاقتصاد في

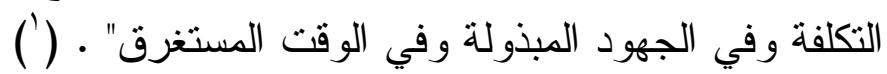

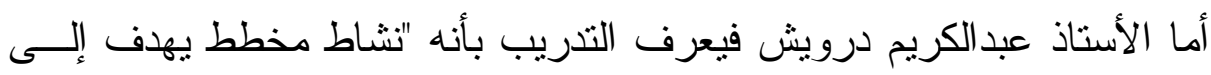

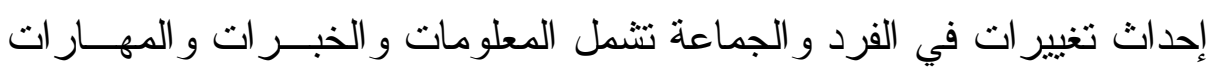

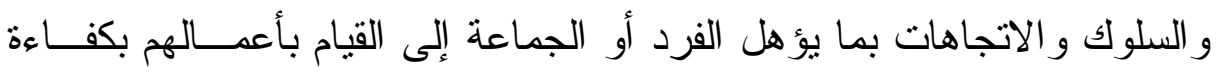

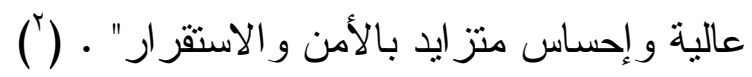
وجاء في كتاب التدريب في نطاق الخدمة العامة الصادر عن الأمم المتحدة بأن الأن

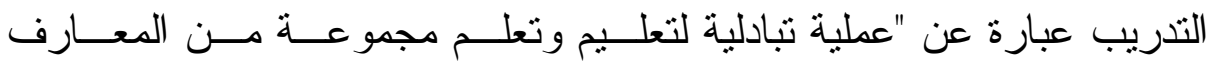

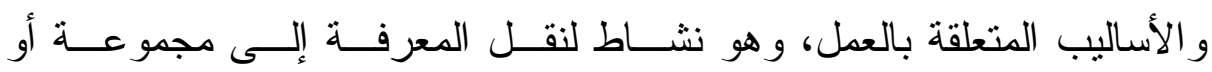

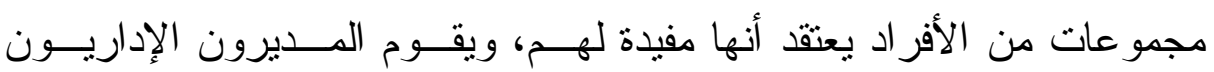

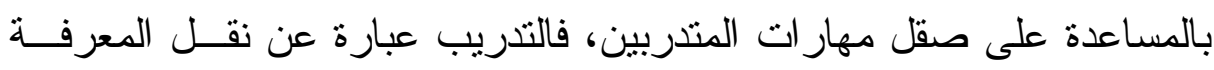

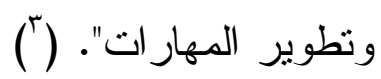

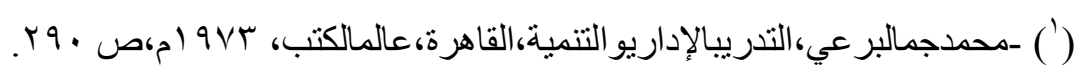

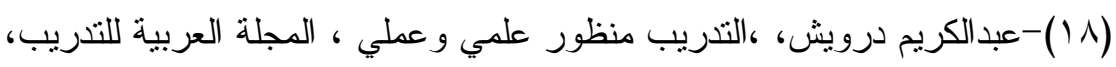

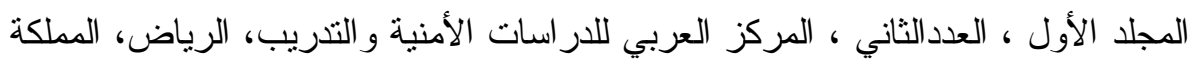

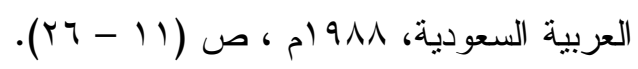
United Nations, Hard Book of Training in the public service, H., I, 1966 pp. 14 et 15$)-19(\mathbf{1 0 0 .}$ 


\section{في ضوء هذه التعاريف، نستطيع أن نستخلص ثيلثة عناصر رئبيبة للت دريب}

أنهه نشاط لنقل المعرفة من أجل تتمية وتطوير نماذج التفكير و أنماط الأفعــال لأفر اد التتظيم( وزارة ، مؤسسة ، جهة إتحادية...) r-أنه صقل مهار ات المتدربين من أجل رفع مستوى الأداء لدى العاملين .

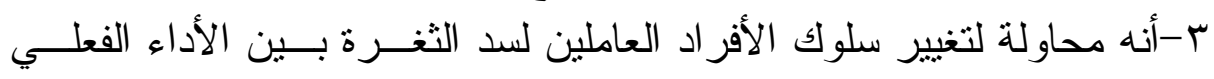
ومستوى الأداء المرجو .

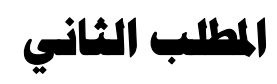

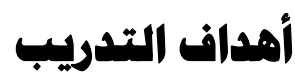

يهدف تدريب الموظفين العمو ميين بصفة عامة إلى رفع كفاية موظفي الدولــة إلى درجة تمكنهم من أداء و اجباتهم الوظيفية على أكمل وجه. وقد بينت المو اد

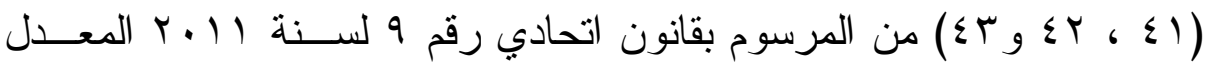

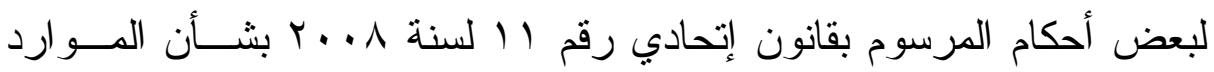

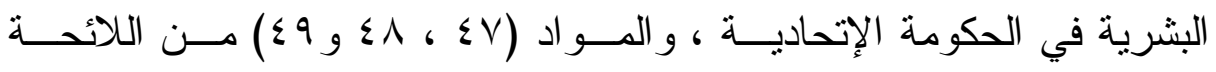

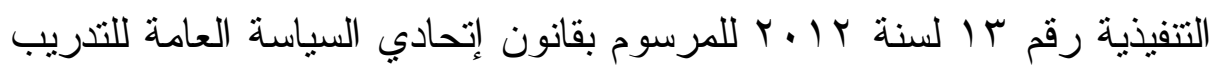
و التطوير في نطاق الوظبفة العامة و أهدافه حيث : تلتزم الوزارات و الجهات الإتحادية بالمحافظة على الكو ادر البشرية المدربـــة و المؤ هلة الثور

r ) وكذلك بتدريب موظفيها وتطوير معارفهم ومهار اتهم وقدر اتهم الوظيفية

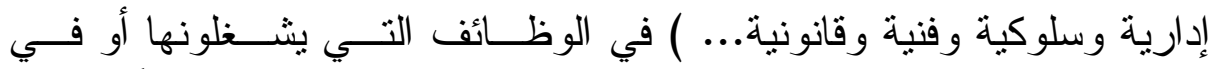

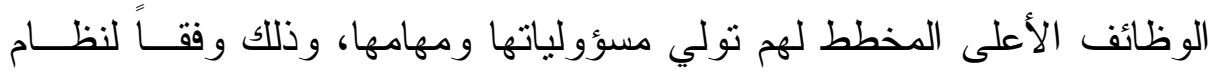
التدريب و التطوير الذي يصدر عن مجلس الوزر اء بناء على اقتـــر اح الهيءــة الإتحادية للموارد البشرية .

الهدف من إيفاد الموظفين في دور ات وبر امج تدريبية داخل أو خار ج الدولــة أو الترخيص لهم بالإلتحاق بدور ات أو بر امج تدريبية داخل الدولة هو متابعـــة

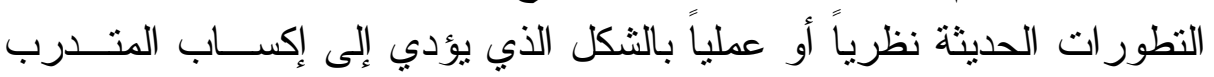
خبر ات ومهار ات إدارية أو فنية أو سلوكية أو عملية بما بؤدي إلى تتميتة فـي التي مجال عمله. 
يجب على الوز ار ات و الجهات الإتحادية أن تضع وتتفذ خططاً سنوية لتـدريب

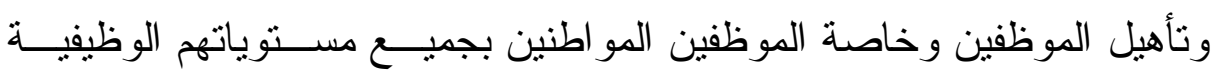

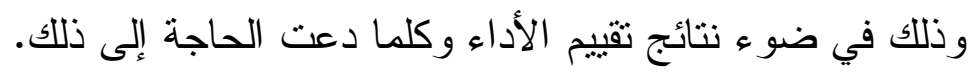

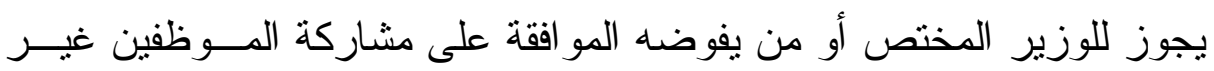
المو اطنين في بر امج تدريبية.

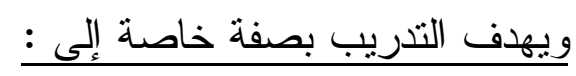
ا-تحسين مستوى أداء الموظفين لرفع كفاءتهم الإنتاجية.

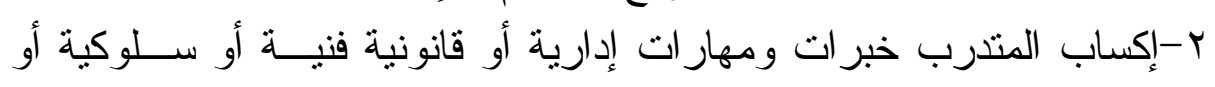
عملية. r-تتمية المعارف لدى الموظفين وخاصة في مجال التنظــيم و الاختصــاص

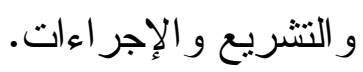

ع -ثقوية مهار ات الموظفين وقدر اتهم على التخطيط و التنسيق و القيــادة وحـلـ المشكلات.

ه-ايجاد علاقات إيجابية بين الموظفين المتدربين ودو ائر هم ومؤسساتهم.

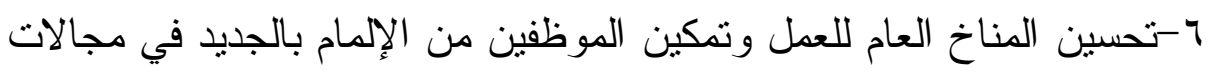
عملهم. V-التغيير في الاتجاهات العامة و الخاصة للموظفين من أجل تتميــة وتطـــــير نماذج التفكير لديهم.

\section{الإلبب الثالث}

\section{أنواع التدريب}

يمكن تصنيف أنواع التدريب من حيث الزمن أو المكان أو الهدف.

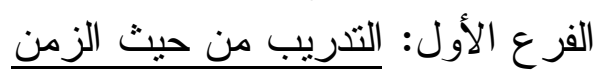

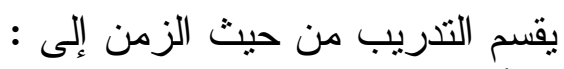
أو لاً: التدريب قبل الالتحاق بالوظيفة

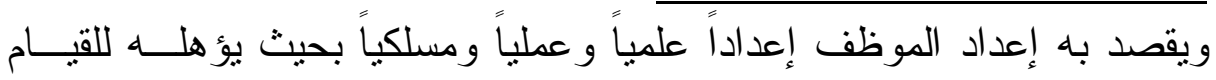

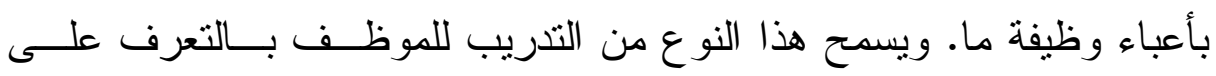

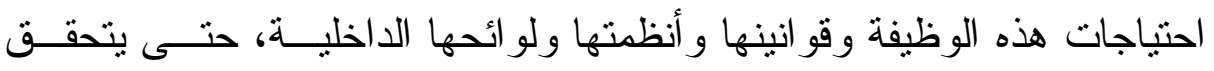
للموظف الإحاطة و الإلمام بوظيفته وبالتالي ضمان استمر اره و انتظامه بالعمل. 


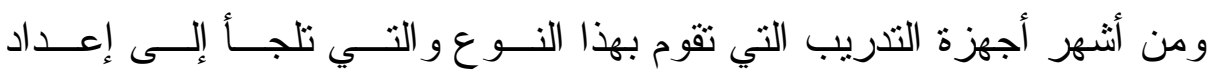
الموظفين على المستوبين النظري و التطبيقي :

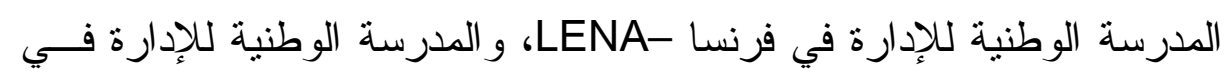

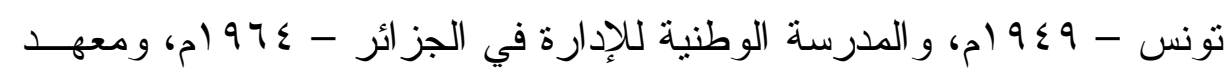

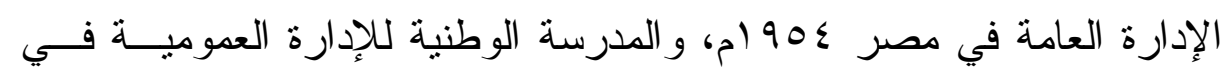

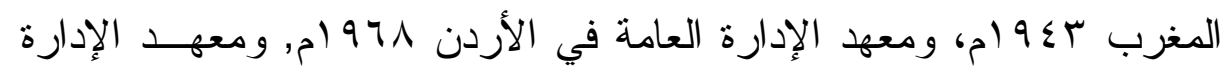

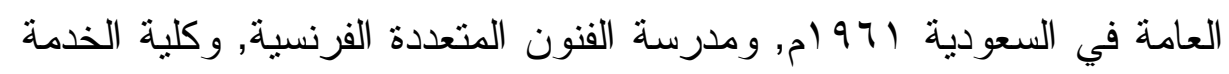

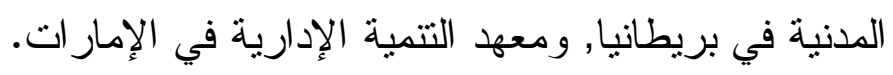
ويشمل التدريب قبل الالتحاق بالعمل بر امج التدريب التوجية الادية الإدية : أ-التدريب التمهيدي التبن

ويشمل التدريب على كل ما من شأنة التعرف على احتباجات وظيفة ما لتمكينه من شغلها بكل جدارة و اقتدار .

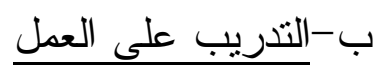

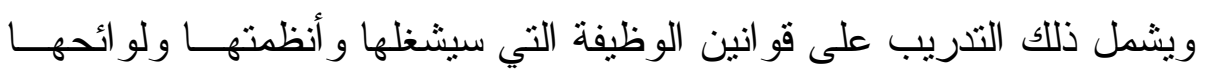

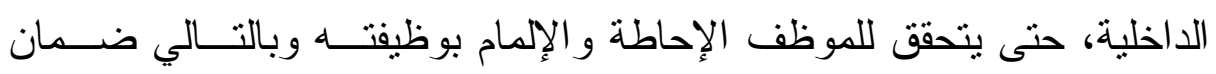
استمر اره و انتظامه بالعمل. ثانباً : التدريب أثناء الخدمة

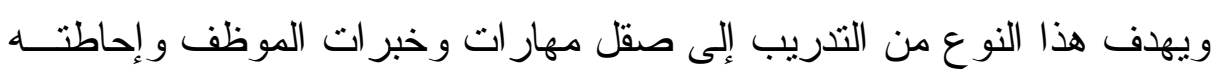
بأحدث التطور ات التي تجد في مجالات العمل وتحسين مستوى أدائه الوظيفي.

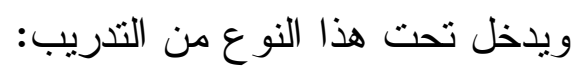

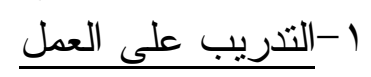

التذريب على كل ما يتعلق بالوظيفة ومقتضياتها، ويكون ذلك أثتــاء ممارســـة العمل.

$$
\text { التذريب خار ج العمل }
$$

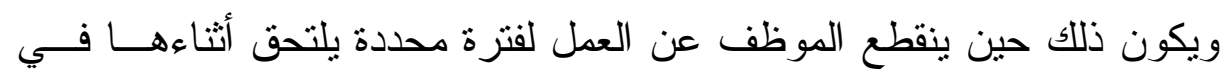

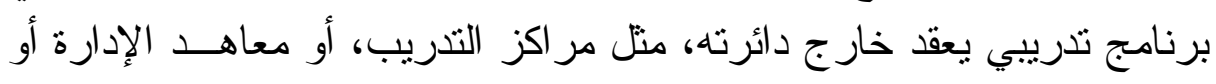
الكليات أوفي مر اكز التعليم المستمر في دائ الجامعات. 


\section{الفرع الثاني \\ التدريب من حيث المكان}

يتخذ التدريب من حيث المكان صورتين :

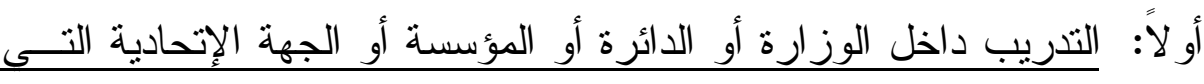
يعمل بها الموظف

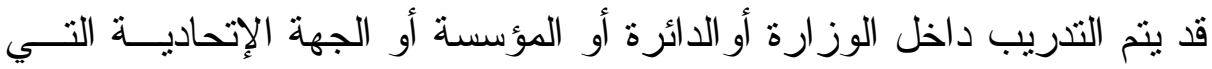

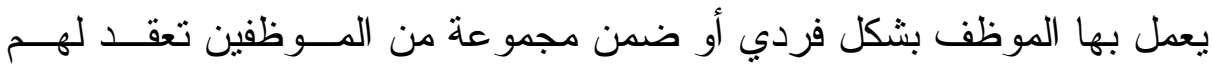

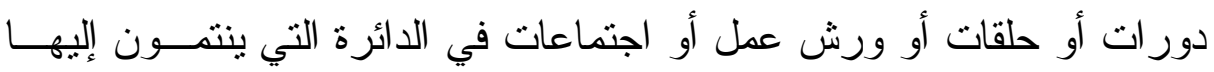

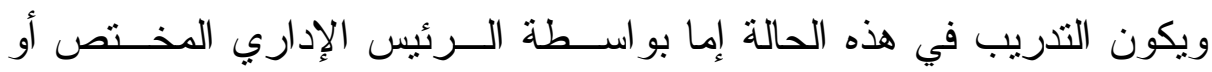

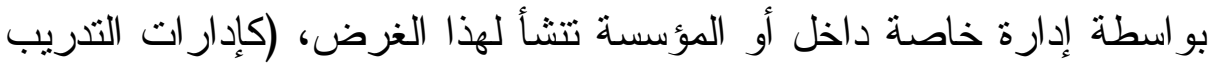
و التطوير و التخطيط).

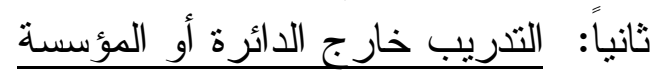

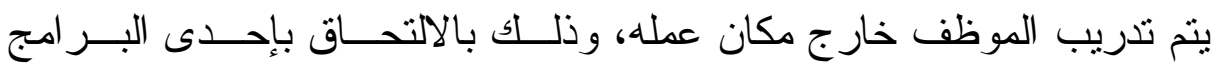

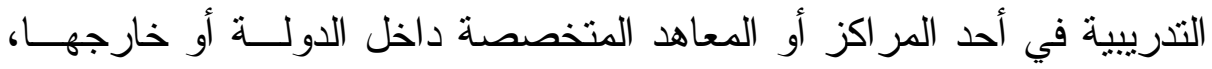
كالجامعات أو المعاهد الإدارية أو مر اكز التدريب المتخصصة.

\section{الفرع الثالث}

\section{التدريب من حيث الهدف}

يتخذ التشريب من حيث الهدف صور اً وأثنكالاً متعددة : أو لاً: التنريب لتجديد من حلثيد المعلومات

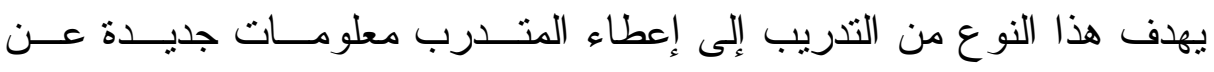
مجالات عمله وأساليبه ووسائله المنطورة.

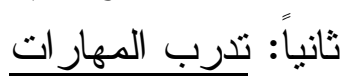
ويهدف هذا التدريب إلى زيادة قدرة الموظفين على أداء أعمال معينـــة ورفــع

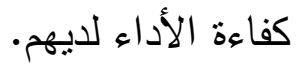
ثالثاً:التنريب السلوكى (تدريب الاتجاهات)

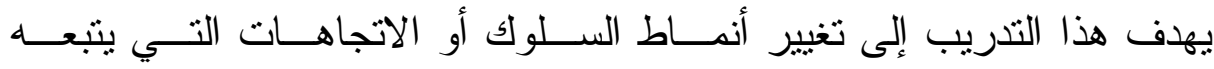
المديرون في أعمالهم. رابعاً : التندريب للترقية ألتمانية 
يهذف هذا النوع من التذريب إلى تحسين إمكانيات الموظــف بغيــة تحســين

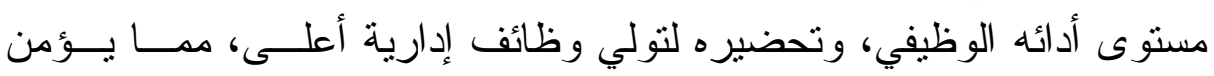
للموظف مجالات التزقية.

\section{البمث الثاني}

تمديد وتمليل احتياجات التدريب (استزاتيميات التدريب)

أن مصداقية العملية التدريبية ومدى فاعليتها تعتمــد علـىى دقــة ومصــداقية در استها وتحديد وحصر الاحتياجات التدريبية لجعلها حقيقة و اقعية. وقد نظمت

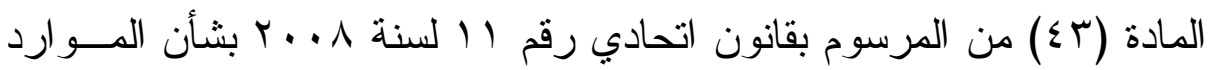
البشرية في الحكومة الإتحادية و المادة رقم (9 §) من اللائحة للمرسوم بقـانون

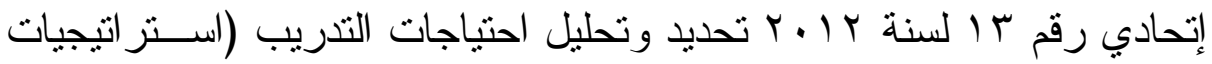
التذربب) من خلال المقومات التالية: مصادر تحديد وتحليل احتياجات التدريب ملب مليب التتسيق بين الموظفين و إدار اتهم و أقسامهم وضع الخطة التدريبية وتعديلها وتتفيذها.

معوقات تتفيذ الخطة التدريبية أساليب تتفيذ الخطة التدريبية • تقييم ومتابعة تقييم الخطة التدريبية. تحديد الاحتياجاتالمستقبليةللتدريب

\section{الإطب الأول}

\section{همادر تمديد وتمليل اهتياجات التدريب}

يتم تحديد وتحليل احتياجات التدريب السنوية لكل وزارة أو جهة اتحادية مــن خلال الأهداف و السياسات الإستر اتيجية سو اء المعتمدة للحكومة أو الــوزار ات

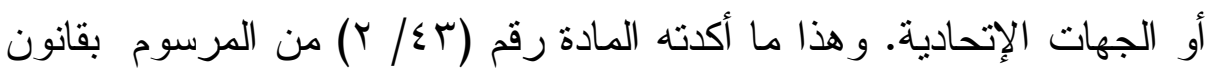

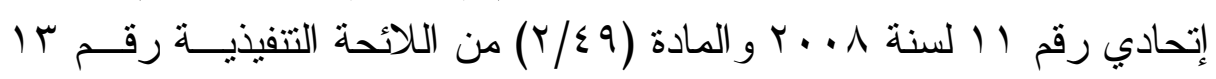




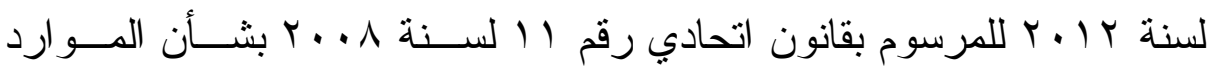
البشرية في الحكومة الإتحادية بقولها " تتولى كل وزارة أو جهة اتحادية تحديد

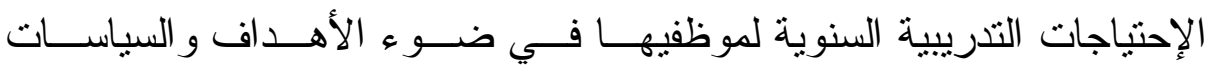
الإستر اتيجية المعتمدة لها، وتحليل احتياجات التذريب و التطـــوير مــن خــلاله

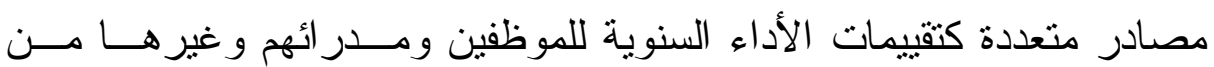

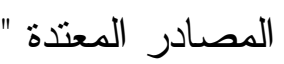
وتلتزم كل وزارة أو جهة اتحادية بتحليل احتياجات التذريب و التطـــير مــن خلال مصادر متعددة تشمل : ا -وصف الوظائف ومقار نتها بالمؤ هلات العلمية و الخبر ات العمليـــة لثـــاغلي مائ الوظائف. r -تقييم كفاءة الأداء السنوي لشاغلي الوظائف. ب-آر اء الرؤساء و المديرين في مو اطن ضعف الأداء التي تحتاج إلـى رفــع كفاءة أداء الموظفين المشرفين عليهم. ع-آر اء الموظفين في مدى حاجتهم لتطوير الكفاءة في العمل. ه-التغيير ات في نظام العمل وظروفه. 7-إعادة الهيكلة وما تتطلبه من تدريب على الوظائف المستحدثة. V-أية مصدر آخر قد تر اه الوز ارة أو الجهة الإتحادية مفيداً.

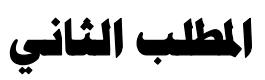

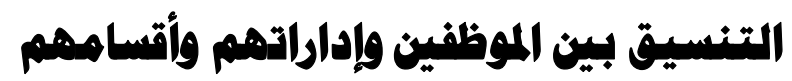

ثقوم إدارة المو ارد البشرية في الحكومة الإتحادية بدر اسة وتحديد الإحتياجـات التدريبية بالتتسيق مع الإدار ات و الأقسام المعنية وموظفيها بهدف : (')

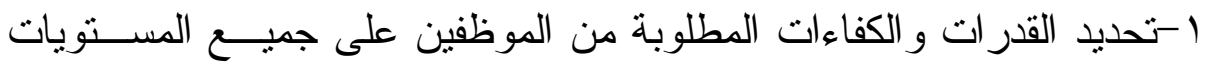
لتحقيق أهداف الوز ارة أو الجهة الإتحادية.

ب-تحديد مستوى المهار ات أو المعرفة اللازمة لتمكين الموظفين من تحســين

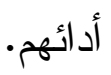

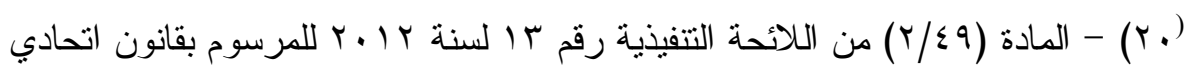
رقم 11 لسنة ^ . . ب بشأن الموارد البشرية في الحكومة الإتحادية . 
ب-تحديد المهار ات و الكفاءات المطلوبة في المســتوى التــالي مــن المســار الوظيفي، و اعداد الموظف لهذه المهار ات و الكفاءات.

\section{الإhب الثالث}

\section{وضع خطة التدريب والتطوير وتعديلها وتنفيذها الفرع الأول}

\section{وضه الفمبة التمدربيبة وتعديلها}

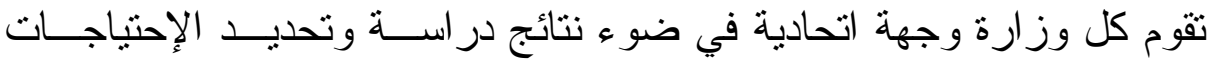

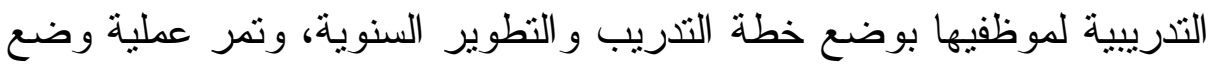
الخطة التدريبية بعدد من المر احل :

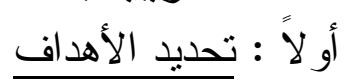

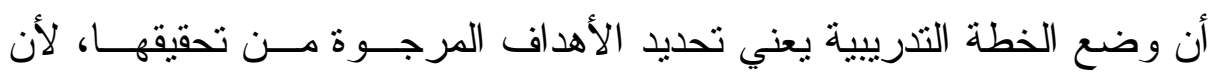

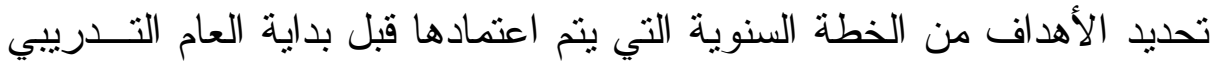

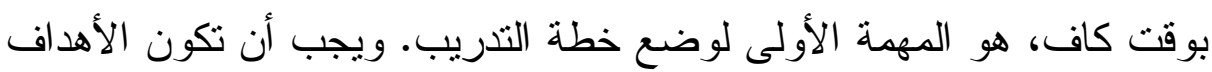
و اقعية يمكن تحقيقها بكفاءة وبالزمن المحدد (').

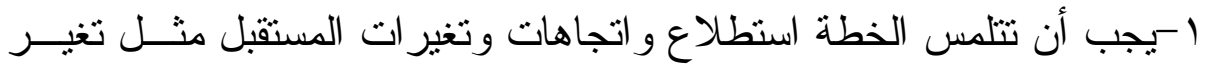
بعض البر امج أو إهمال هدف معين لفترة معينة.

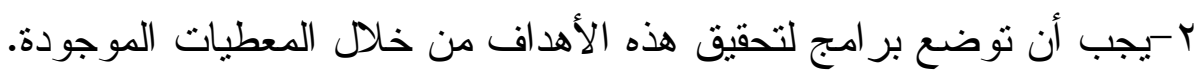

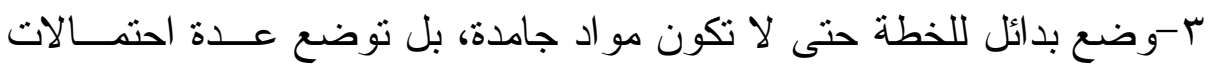
لمو اجهة أية جمود. ع -يجب أن نتوفر بعض الثروط الثخصية في الخطة التدريبية (تــوفر عـدد من الصفات الهامة في المتدربين). ثانياً :تخطبط وتصميج بر امج (مناهج) التدريب

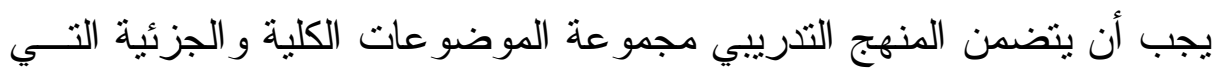
تكفل تضمن تحقيق الهدف العام سو اء كانت موضوعات أساسية وموضو عات أتهات مساعدة وموضو عات أخرى فرعية، على أن نأخذ بعين الاعتبار ما يلي : لهاء

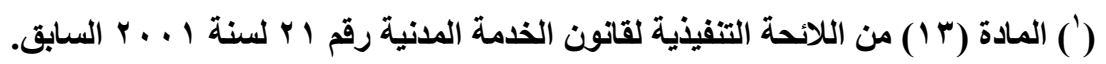
= التلريب والتطوير في دولة الإمارات العربية المتحدة دعامة من دعامات الأمن الوظيفي 
ا-الربط الوثيق بين التدريب و البيئـــة المحيطـــة وتر اعـــي التقــدير الــدقيق لباحتياجات التدريبية.

r-الربط بين البر امج وتحقيق الأهداف النهائية من خلال الأهداف الوسيطة.

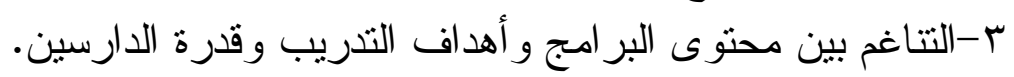
ع -تماثي البر امج مع قابلية التغيير و الاحتمالات.

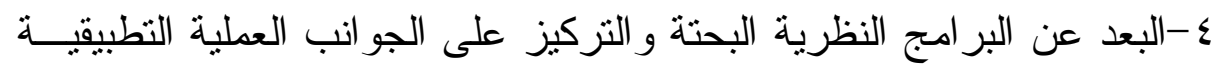
لتو اكب التقنيات المعاصرة.

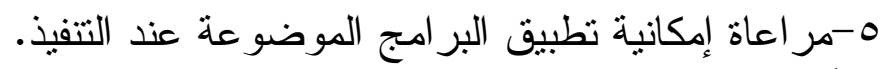
ثالثاً :تعديل الخطة التذرييية يجوز للوزارة و الجهة الإتحادية تعديل خطة التدريب و التطوير السنوية في أي التي التئ

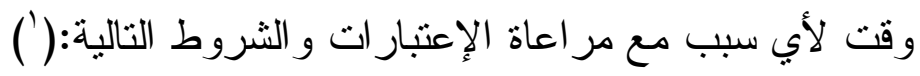
ا-أن يكون الهدف من التعديل مصلحة العمل.

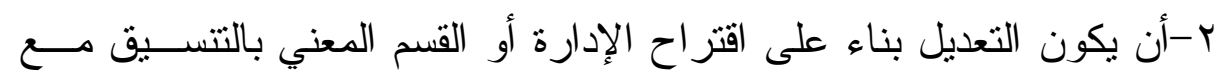

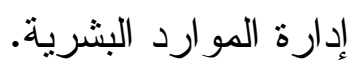
ب-أن يتم اعتماد التعديل من قبل السلطة المختصة.

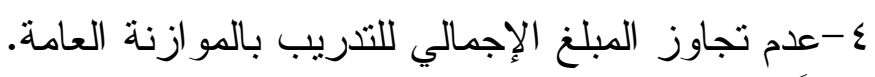
رابعاً : تتفيذ الخطة التذريبية تتولى إدارة الموارد البشرية مسؤولية تتفيذ خطة التدريب و التطــــوير الســـوية بعد اعتماد الموازنة.

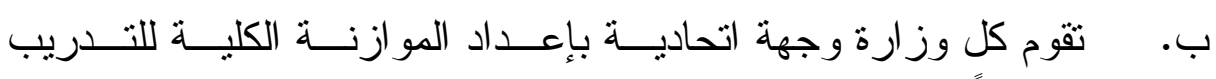

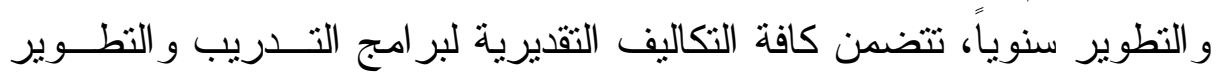

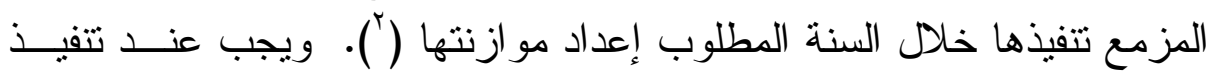
الخطة التدرييية مر اعاة المعايير التي تعتبر من مقومات التنفيذ وهي:

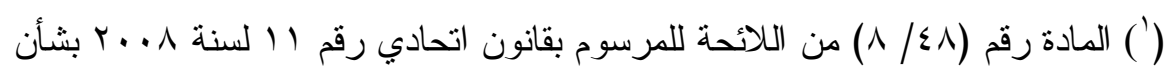
الموارد البشرية في الحكومة الإتحادية.

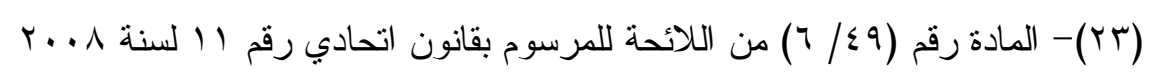

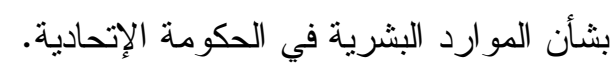


العدد الأول - الجزء الثاني- السنة الثامنةوالخمسون- يناير Vا.r

$$
\text { أنوع التذريب الوظيفي. }
$$

r-مستوى المتدربين و عددهم ومدى استيعابهم لبر امج الخطة التدريبية. ب-ثقدير المستوى الثقافي للمتدرب و عدد المدربين و إمكانياتهم. ع-مر اعاة البعد النفسي للمتدربين. ه-تأمين المكان المالأم لتتفيذ الخطة التدريبية. ج-تحديد مو عد وزمان تتفيذ الخطة التدريبية و إبلاغها للجهات المعنية بوقــت كاف.

\section{الرطب الرابج}

\section{معموقات تنفيد الفمطة التدروبيبية}

قد تعترض تتفيذ الخطة التدريبية العديد من المعوقات و أهمها : ا-عدم تحديد الاحتياجات التدريبية بشكل سليم.أي عدم القدرة على التخطـيط بطريقة علمية وفنية وعملية في تحديد الإحتياجــات التدريبيــة لعــم وجــود متخصصين أو مؤهلين في هذا المجال.

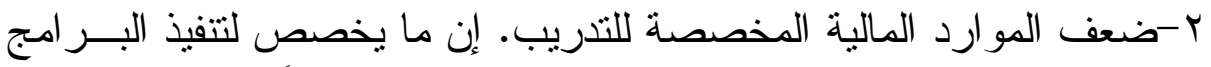
و الخطط التدريبية من الموارد المالية عادة ما يكــون قلـــلاً لعــدم الإهتمـــام بالتدريب الوظيفي.

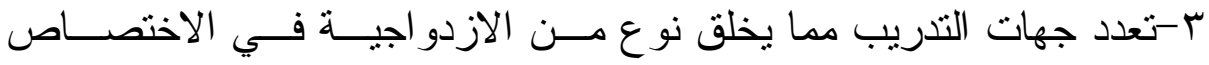

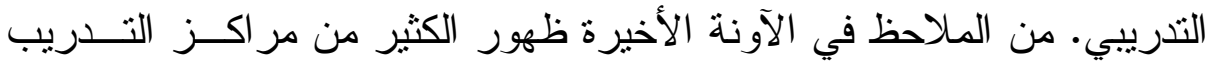
العامة و الخاصة. צ-عدم وجود كفاءة متخصصة قادرة على التدريب أو قلة عددها. 0-عدم وجود معايير و اضحة لتقييم عائد التدريب. 7-عدم وجود منابعة جدية وحقيقية لمخرجات التدريب.

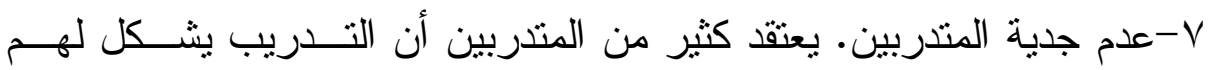
فرصة للخروج من العمل و لا يأخذون التذريب على محمل الجد لعدم وجـود متابعة حقيقية من قبل إدار اتهم لمخرجات التدريب.

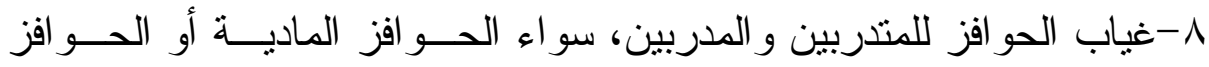
المعنوية. من الملاحظ أن هنالك عزوفاً من كثير من المتخصصسـين و أســاتذة الجامعات على التدريب لقلة العائد المالي من التدريب. 


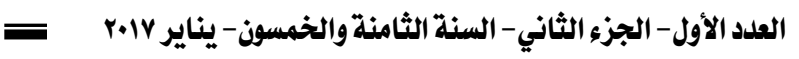

\section{الإطبا الخامس}

\section{أساليب تففيذ الفطة التدرببية}

أساليب التدريب أصبحت كثيرة ومتتوعة ولكل منها فعالية معينة في تحسـين المستوى، ومن هذه الأساليب :

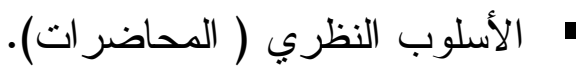

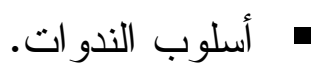

أسلوب جلسات العمل الجماعية. أسلوب جلسات النقاش. • أسلوب ورش العمل.

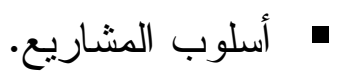
أسلوب المشاريع الميدانية المصورة. أسلوب المشاريع الميدانية على الطبيعة.

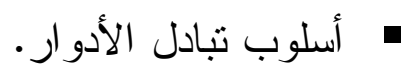

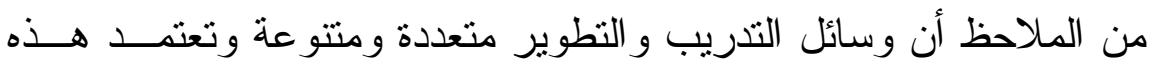

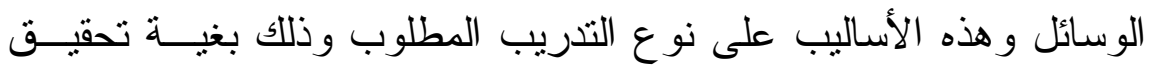

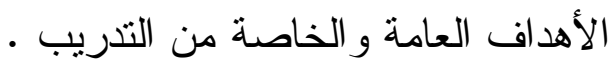

\section{الإلب السادس}

\section{تقيسيم ومتابعة ققيبيم الفطة التدريبية}

تلتزم إدارة الموارد البشرية بتقييم عملية التدريب من خلادل مايلي : ا-ثقييم بر امج التدريب للتأكد من سلامة المعلومات الحقيبة التدريبية من جميع النو احي العلمية و العملية و الفنية و المسلكية.

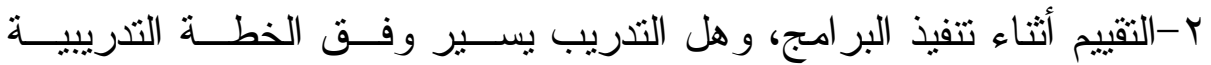
المعتمدة 


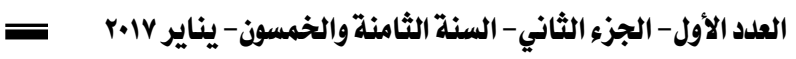

$$
\text { r-التقييم الثخصي للمتدرب. }
$$

ع -تقييم المدر اء لأثز التدريب على أداء الموظفين المتدربين. ه-ثقييم الجهة المنظمة للتنريب. ج-أية وسائل أخرى تستعمل لتقييم التدريب و أثزه.

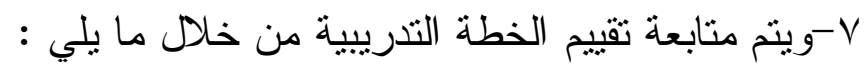

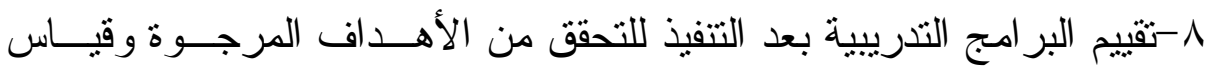
العائد منها. 9-يتم التقييم تبعاً للقق اعد و التعليمات النافذة في الدولة.

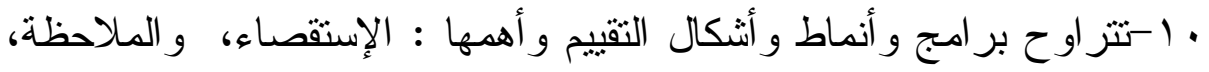
و الاختيار , و الاتصال الثخصي, و المقابلة الثخصية.

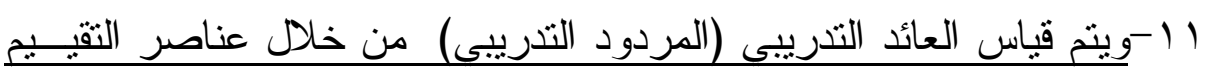
التالية : أ-قياس فاعلية التدريب و العائد الذي تحققه في رفع مستوى أداء العاملين فـي مجال العمل. ب-قياس رد فعل و انطباع المشاركين بالبرنامج.

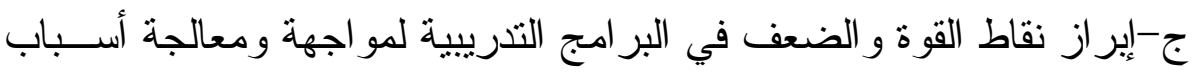
القصور • د ستوثيق نتائج التقييم وتوخي قياس الجودة الثناملة بالتطبيق.

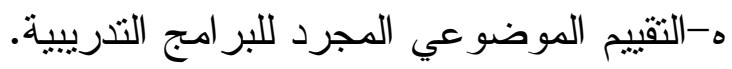
و -قياس التغير في سلوك المتدربين لمعرفة مستوى أدائهر. ز -قياس النتائج مع مر اعاة شكاوي في المتدربين.

\section{الإطاب المسابع}

\section{تمديد الامتياجات المستقبلية لاتدريب}

أن تحديد الإحتياجات المستقبلية للتدريب يحتاج إلى الأخذ بعين الإعتبار العديد

$$
\begin{aligned}
& \text { من الإعتبار ات أهمها: } \\
& \text { دعم وتطوير مؤسسات التذريب } \\
& \text { القياس العلمي للاحتياجات التدريبية }
\end{aligned}
$$


العلد الأول- الجزء الثاني- السنة الثامنة والخمسون- يناير Vا.r.

- أهمية العنصر البشري و إعداده في مجال العمل

\section{• استخدام التقنيات التدريبية}

• آليات تتفيذ الاستر اتيجية المستقبلية للتدريب

\section{الفرع الأول}

\section{دمم وتطوير هومسسات التدوريب}

يكون دعم وتطوير مؤسسات التدريب عن طريق :

ا -دعم وتطوير مؤسسات التدريب بالإمكانات المادية و الفنية.

r-نطوير المؤسسات التجريبية وتحديث أسالييها.

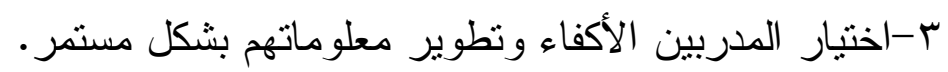

ع -غرس مفهوم التدريب بين مختلف فئات الموظفين.

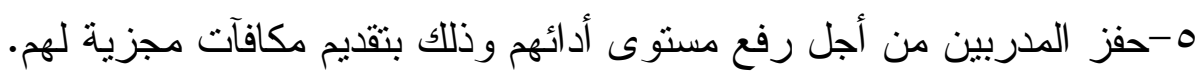

\section{الفرع الثناني}

\section{القياس العلمي للامتياجات التدريبية}

يكون القياس العلمي للاحتياجات التنريبية عن طريق : 1-استخدام الطرق العلمية في تحديد الاحتياجات التدريبية. r-اختيار بر امج تدريبية مناسبة.

r-تشجيع البحث العلمي في مجال تحديد الاحتياجات التدريبية. ع -متابعة تحليل الاحتياجات التدريبية وتعديلها حسب البحلي المقتضى.

\section{الفرع الثشالث}

\section{أهمية العنصر البشري وإعداده في مبال العمل}

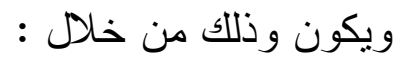

ا-نو ع الوظيفة ومسئولياتها وسلطاتها.

r-تنوع العنصر البشري.

r-العنصر البشري في ظل المتغير ات الإجتماعية والإقتصادية..... 


\section{الفرع الرابه \\ الستفدام التقنيات التدريبية}

يكون استخدام التقنيات التدرييية من خلال :

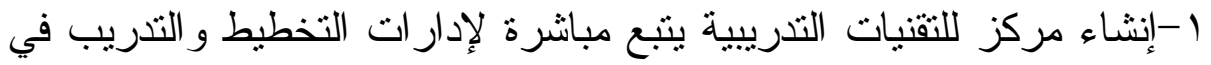

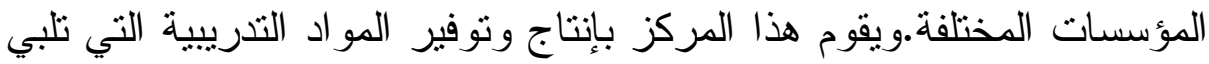

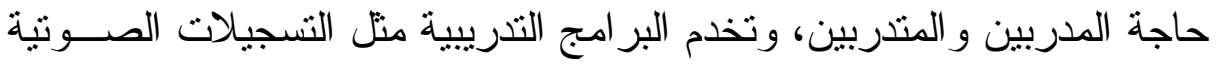
و المرئية و الثر ائح و الصور و الرسوم و والخر ائط و الأفلام التذريبية....إخخ).

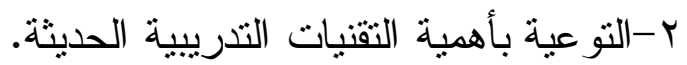
ب-ثقييم البر امج التدريبية السابقة وقياس العائد أو المردود منها لأخذها بعـين الاعتبار في تحديد الاحتياجات المستقبلية.

\section{الفرع الغامسن}

\section{آليات تنفيذ الاستزاتيمية المستقبلية لاتدريب}

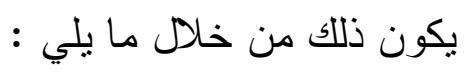

ا-توفير الكو ادر المؤهلة من القادة و الفنيين لأجهزة التدريب الحديثة مع إعادة

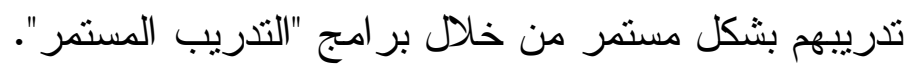

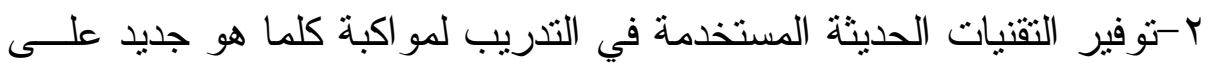

$$
\text { بستوى الأجهزة و الأدو ات و المعداء شتبكة الحديثة. }
$$

- معلومات عن التكنولوجيا المتاحة في مجالات الوظيفة العامة. - معلومات عن مر اكز التدريب و المعاهد و الجامعات. - معلومات عن المدربين الخبر اء و المتخصصين. - معلومات عن البحوث و الدر اسات في مجال التدريب. - معلومات بر امج التدريب المحلية و الإقليمية و الدولية.

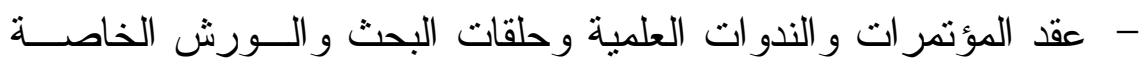
بالتدريب الوظيفي. ع -العمل على إنشاء منظمة متخصصة في مجال التـدريب تعنــى بــالبحوث و الدر اسات الخاصة بالتدريب. 
ه-إيفاد بعض الموظفين في عمل بحوث ودر اسات في مجال التـدريب فــي

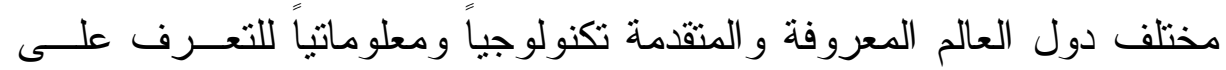
أحدث الأساليب و النظم التقنية التدريبية.

\section{المبحث الثالث}

\section{الإيفاد في الدورات والبرامه التدريبية}

يكون إيفاد الموظفين في دور ات وبر امج تدرييية سو اء داخل الدولة أو خارجها

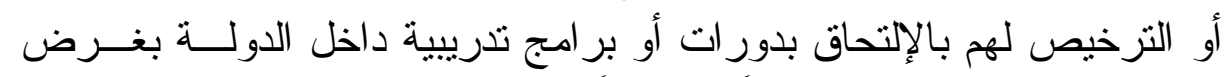

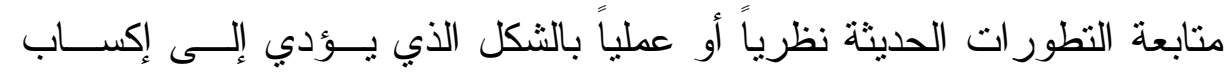

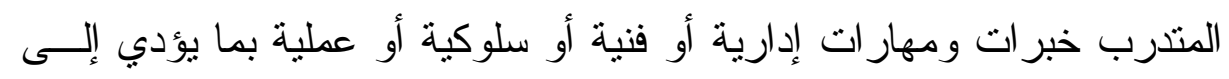
تتميتة في مجال عمله. وتتولى الوزارات و الجهات الإتحادية تحديد الإحتياجات

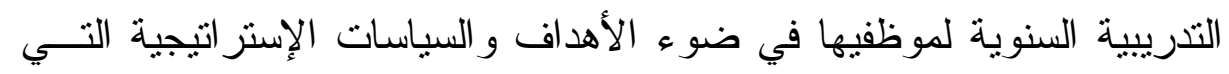

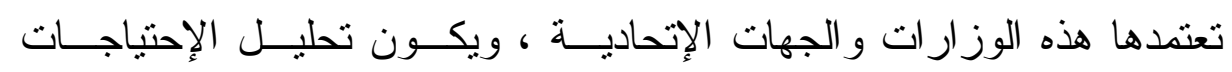

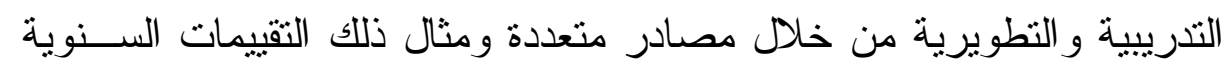

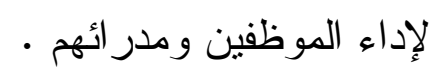
ويجب تو افر العديد من الثروط في الدور ات و البر امج التدريبية سو اء شــروط

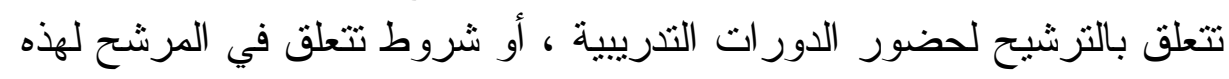

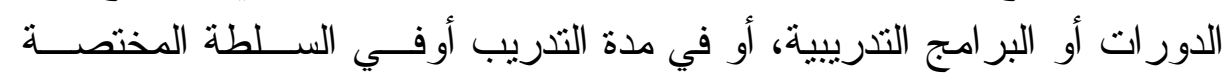

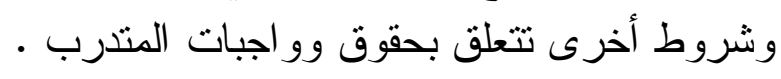

\section{الإلأول}

\section{شـروط تتعلق بالترشيه لمضمور الدورات أو البرامج التدريبية}

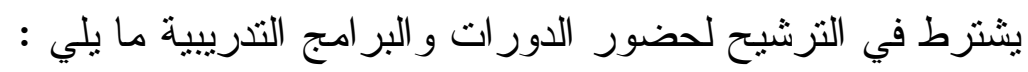

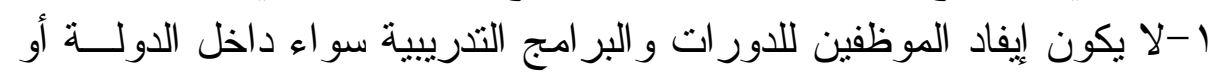
خارجها إلا في حدود المخصصات المالية المعتمدة لها.

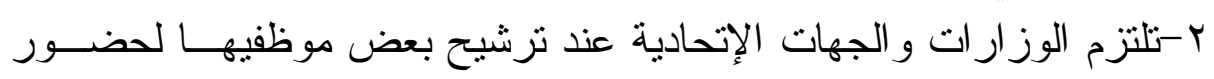

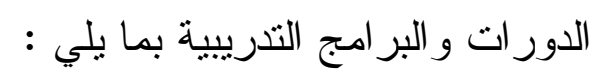

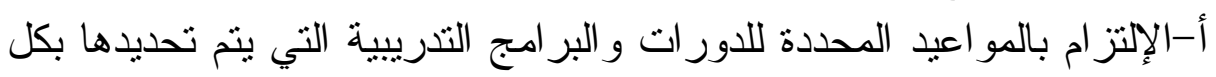
دقة من جانب جهات التدريب بالخارج. 


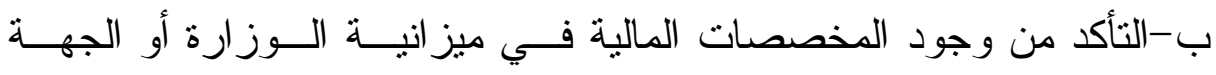

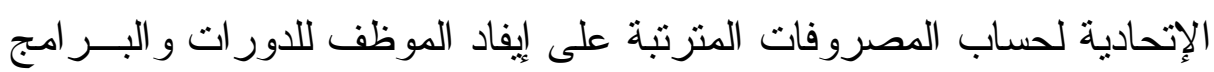
التدريبية.. ج-حرمان الموظف المرشح الذي يعتذر عن حضور دورة تدريبية أو برنامج تدريبي لأسباب غير مقنعة من الترشح لأي دور ات أو بر امج تدريبية لمدة ستة دونة

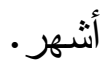

\section{الامطاب الثاني}

\section{شـوط تتعلق بالإيفاد للدورات أو البرامهج التدريبية}

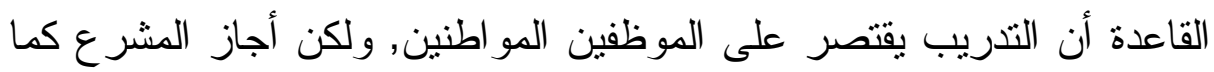

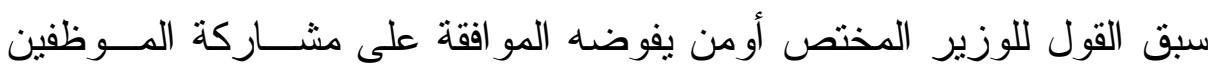
غير المو اطنين في بر امج در اسية. ويشترط لإيفاد الموظف في دورة أو برنامج تدريبيى ما يليى : درئي 1-الحصول على مو افقة جهة التدريب وذلك من خلال السلطة المختصة بذلك

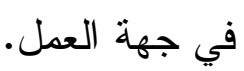
r-أن يكون للدورة أو البرنامج التدريبي علاقة مباشرة بالعمل الذي يقوم بــــ

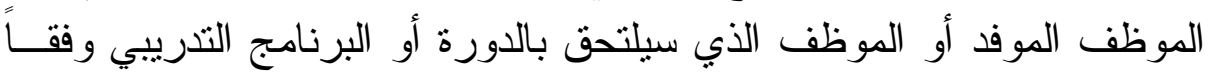

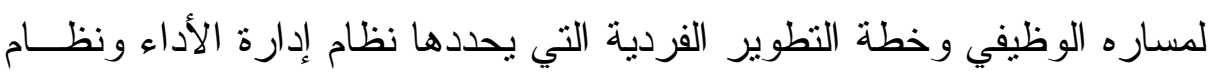

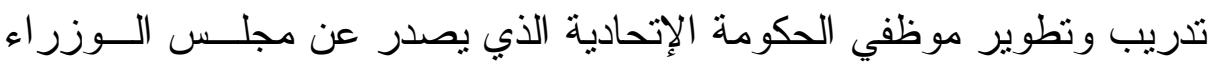

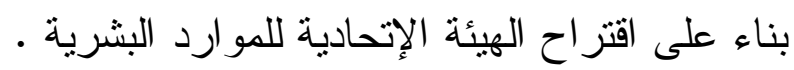

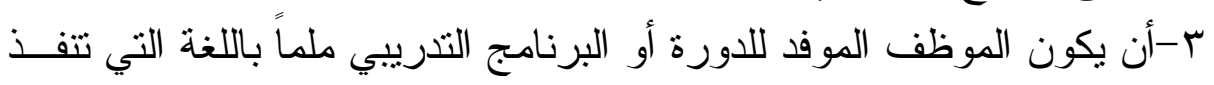
بها الدورة أو البرنامج التدريبي بدرجة تمكنه من الإستفادة منها.

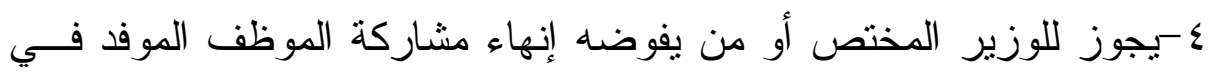

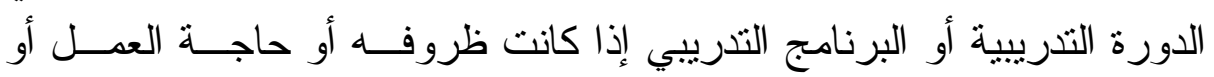

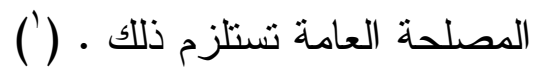

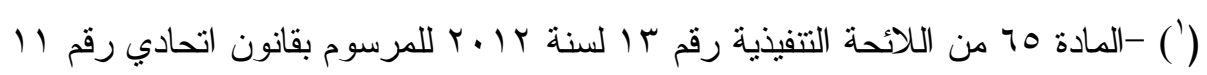
لسنة ^... r بشأن الموارد البشرية في الحكومة الإتحادية. 


\section{الإباب الثالث}

\section{شـروط تقعلق بواجبات الموظف الموفد للدورات والبرامهة

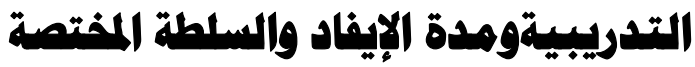

\section{الفرع الأول}

\section{شروط تتعلق بواببات الموظف الموفد للدورات والبرامه التدريبية}

يلتزم الموظف الموفد في الدورة أو البرنامج التدريبي بما يلي : ا-المو اظبة على حضور الدورة أو البرنامج التدريبي. r-المحافظة على سمعة الدولة.

r-احتر ام قو انين وتقاليد الدولة التي يفد اليها الموظف الموفد لحضور الــدورة أو البرنامج التدريبي.

ع-ثقديم تقرير مفصل عن الدورة أو البرنامج التدريبي الموفد اليه الموظف.

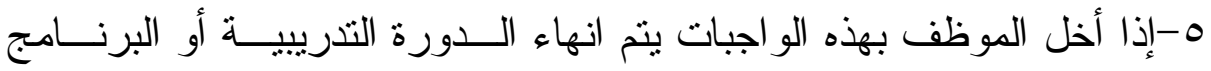
التذريبي، ويلتزم الموفد برد كافة المخصصات الماليةالتي صرفت لثون له.

\section{الفنرع الثماني}

\section{شـروط تقعلق بمدة الإيفاد للدورات والبرامه التدريبية}

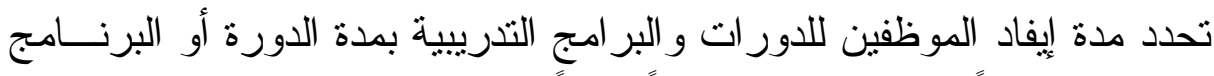

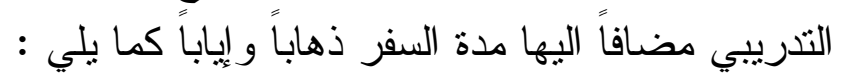

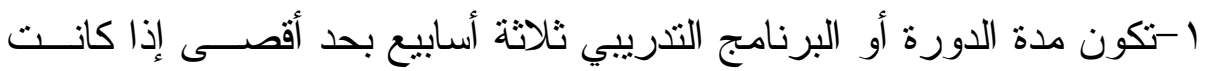

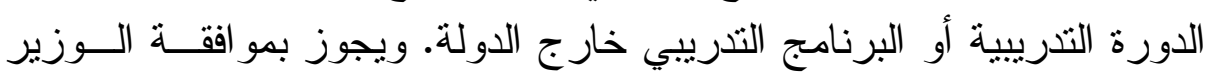
المختص منح الإسنتثاء إذا ز ادت المدة على لئل ذلك.

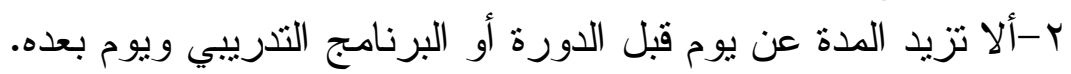

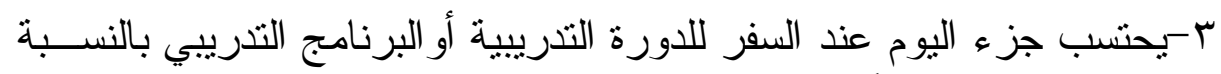

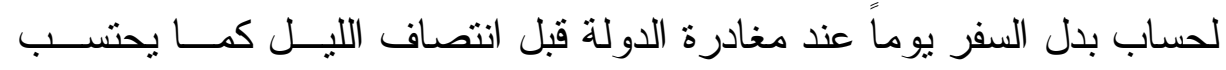
جزء اليوم يوماص عند العودة إلى الدولة بعد انتصاف الليل بتوقيت الدولة التها.

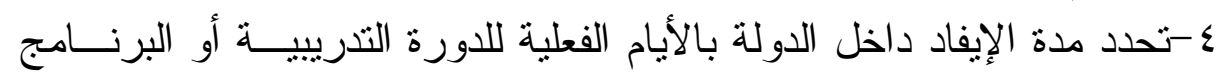

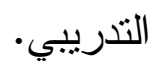




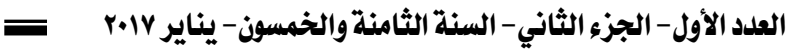

\section{الفمع الثخالث}

\section{الساطة المفتصة بإصدار قرار الإيفاد للدورات والبرامه التدريبية}

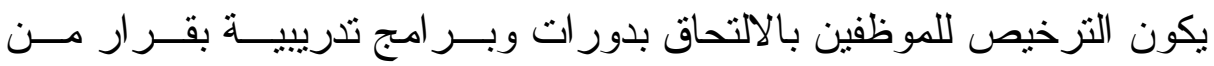

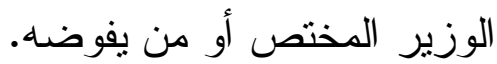

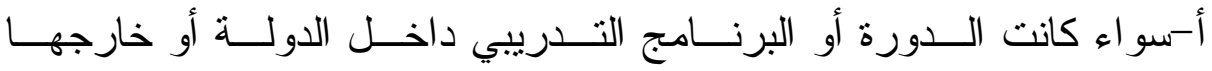
بمصروفات أو بدون مصروفات.

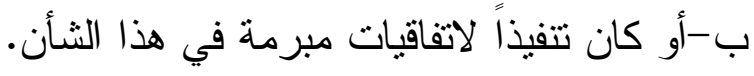

\section{الإطبب الرابع}

\section{شروط تتعلق بالمفمصات الالية للموظف الموفد للدورات والبرامهج}

\section{التدريبية}

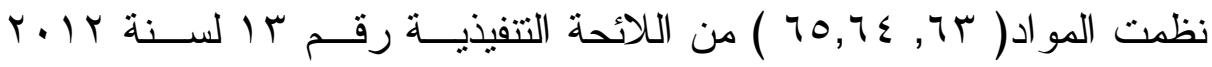

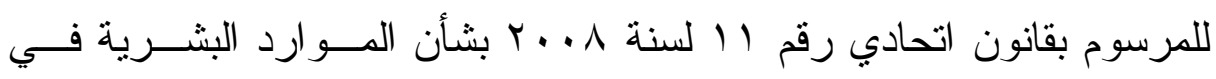

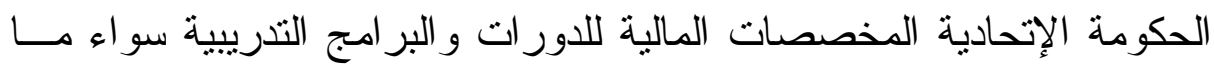
يتعلق ببدل السفر أو تذادكر السفر أو النفقات الأخرى.

\section{الفرع الأول}

\section{بدل السفر ( بدل الإيفاد )}

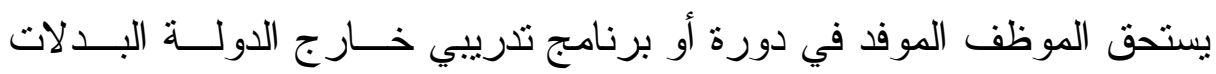

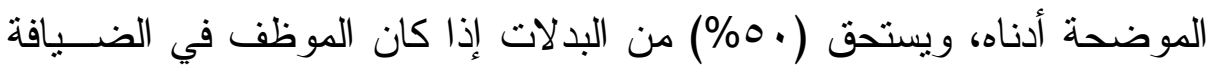

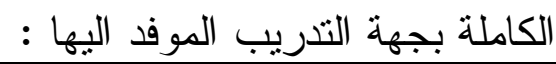

\begin{tabular}{|c|c|c|}
\hline الضيافة & الضيافة & وظيفة الموفد ودرجته الوظيفية \\
\hline 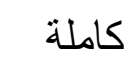 & بدون & \\
\hline $10 \ldots$ & r... & في حكمهواء الوزار ات و الوكلاء المساعدون ومسـن \\
\hline 1 ro. & ro.. & 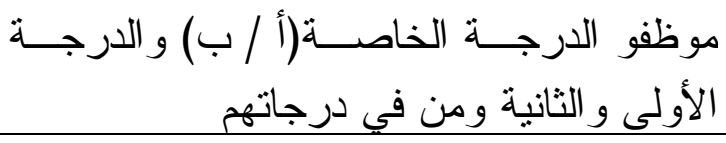 \\
\hline $1 \ldots$ & $r \ldots$ & موظفي الدرجة الثالثة فما فوق \\
\hline
\end{tabular}




\section{الفرع الثانبي}

\section{نفقات الإوظف المبتعثش}

أ. تتحمل الوز ارة و الجهة الإتحادية نفقات الإقامة و المعيشة للموفد في دورة أو الو الو

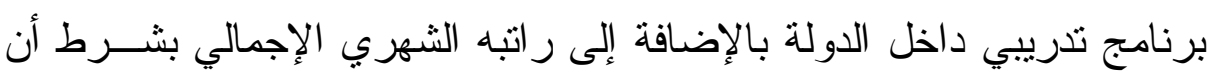

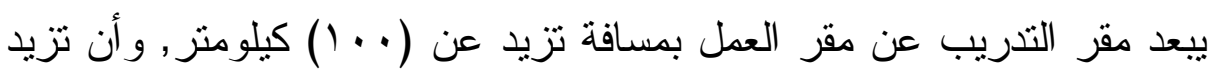
الدورة التدريبية عن يوم و احد.

ب-يعتبر الموظف الموفد في دورة تدرييية أو برنامج تدريبي" خارج الدولة "

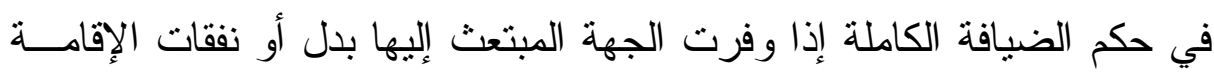

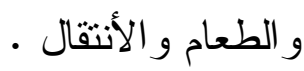
ج-إذا لم تقم الجهة الموفد إليها الموظف أثثاء الدورة التدرييـــة أو البرنــامج

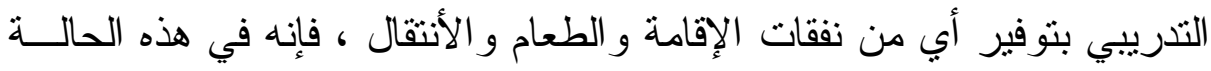

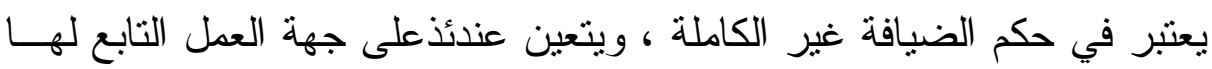

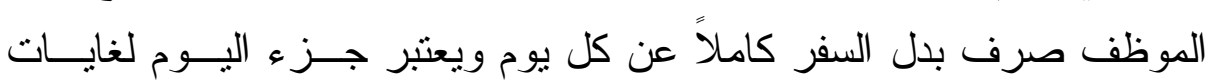

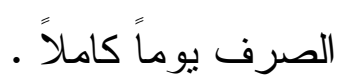

\section{الفرع الثشالث \\ تذاكو البنفو}

يستحق الموظف الموفد في دورة تدريبية أو برنامج تدريبي التذاكر التالية : تذكرة سفر للموظف من مقر العمل بالدولة إلى البلد الموفد اليه وبالعكس.

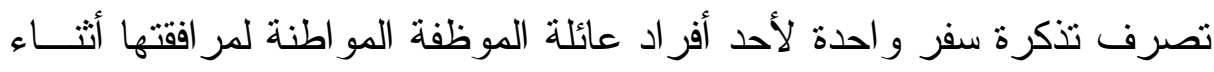

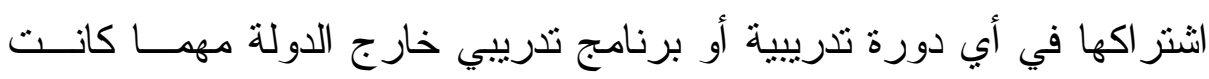
مدته، وذلك بنفس درجة السفر المقررة للموظفة الموفدة.

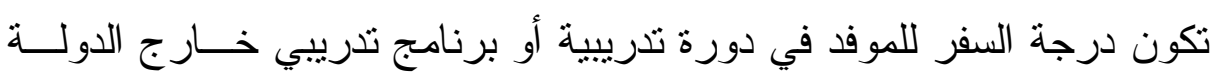
وققاً للجدول التالي : 
العدد الأول- الجزء الثاني- السنة الثامنة والخمسون- يناير V ا. P

\begin{tabular}{|c|c|}
\hline درجة السفر & الدرجة الوظيفية \\
\hline 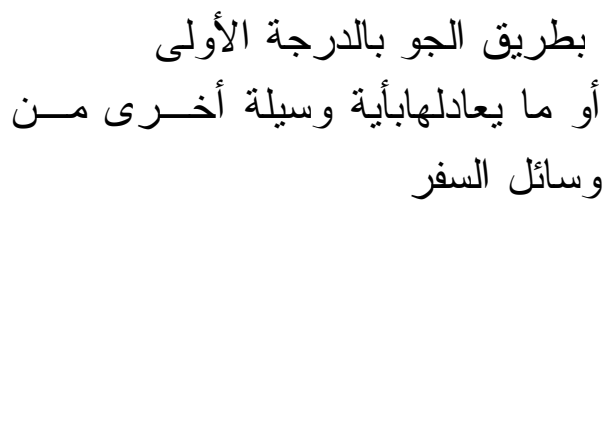 & 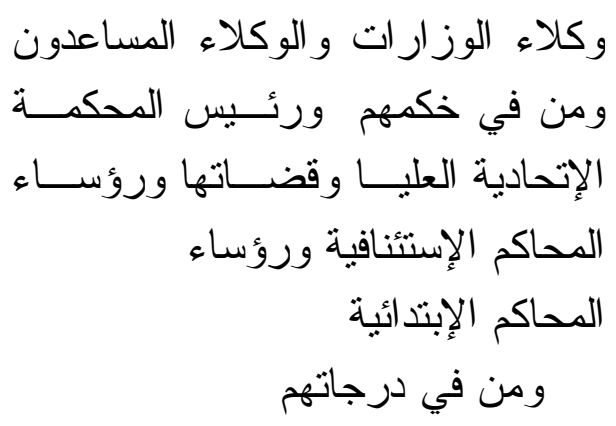 \\
\hline 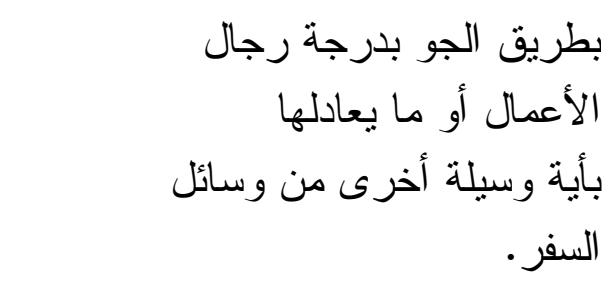 & 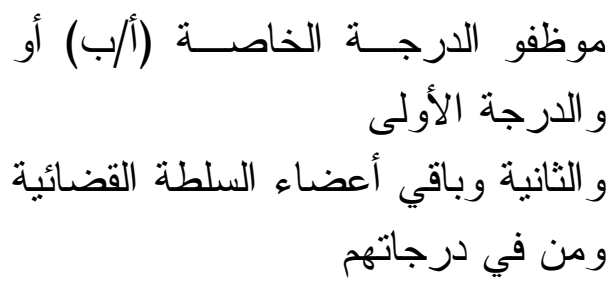 \\
\hline بطريق الجو بالدرجة السياحية & فما فوقفون من الدرجة الثالثة \\
\hline
\end{tabular}

\section{النمرع الزابه

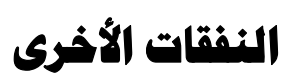

يستحق الموظف الموفد في دورة تدريبية أو برنامج تدريبي :

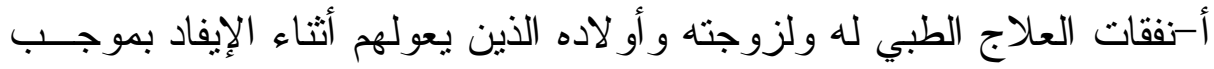

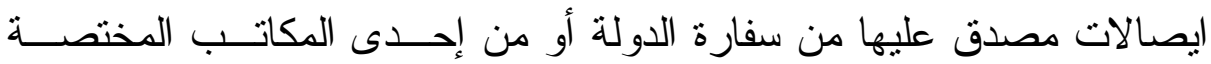

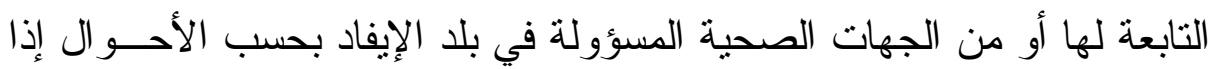
كانت مدة الإيفاد تزيد عن ستة أثهر . ب-تقوم جهة العمل باستخر اج التأثيرات اللازمة وسئه وسداد الرسوم اســتخر اجها من الجهات المعنية. 


\section{الخاتمة}

لقد سبق التأكيد على أن التدريب و التطوير و التأهيل الوظيفي ســـو اء كــان

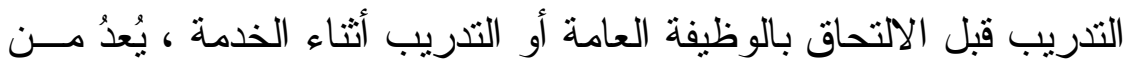

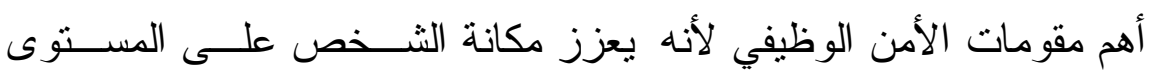

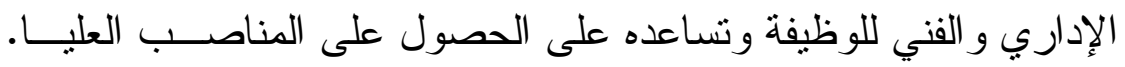

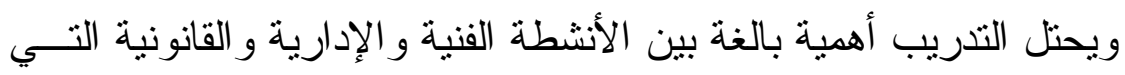

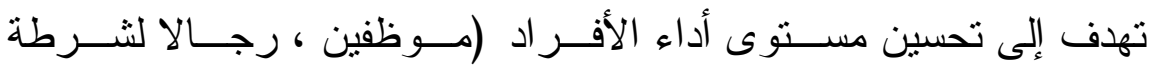

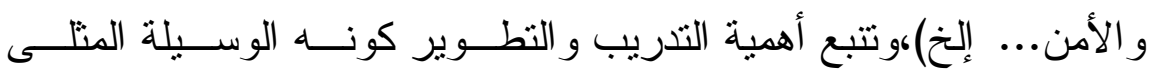
لأحداث التغيير الإيجابي المطلوب في مهار ات الأفئ الأفر اد.

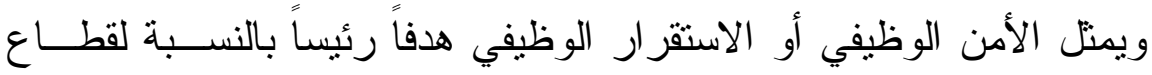
كبير من المو اطنين في أي دولة من الدول ، خاصة وأن هذا القطاع يشكل

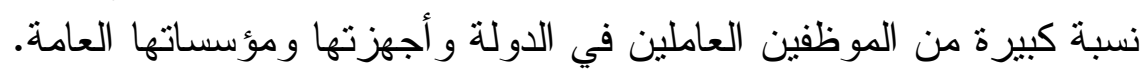

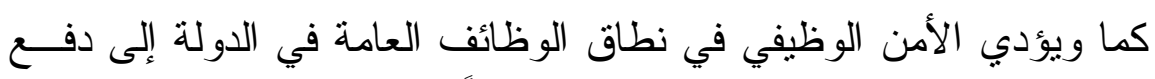

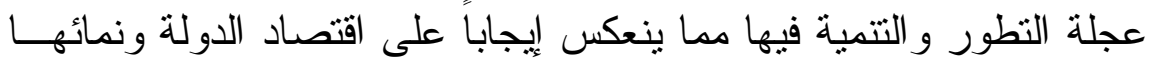

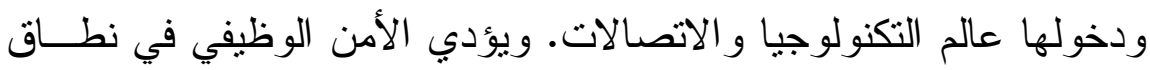

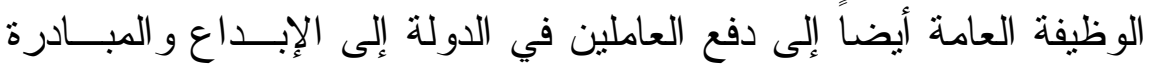

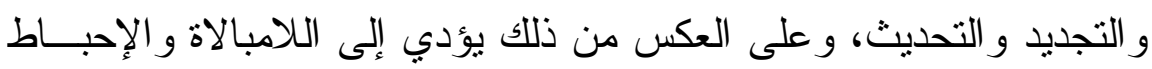
و الفساد الإداري و المالي. و ولئ. وبالنتيجة يحقق الأمن الوظيفي العديد من الامتياز ات و الضمانات للموظف

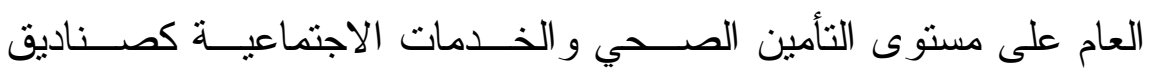

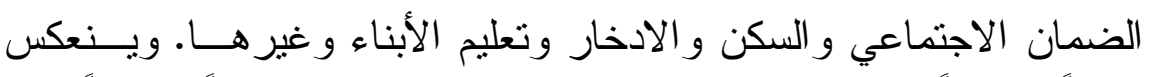

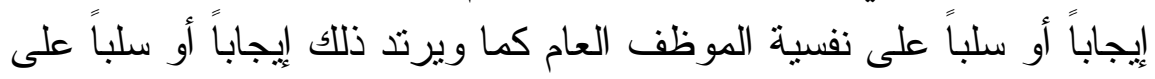
عائلته و أسرته.

ولقد أولت دولة الإمار ات العربية المتحدة عناية هامة لتدريب وتطوير وتأهيـلـ لتهل

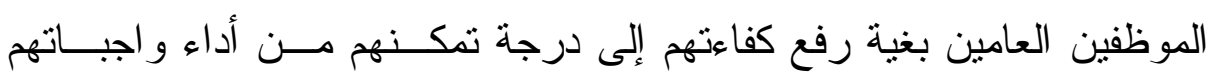

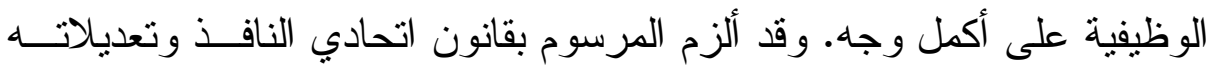

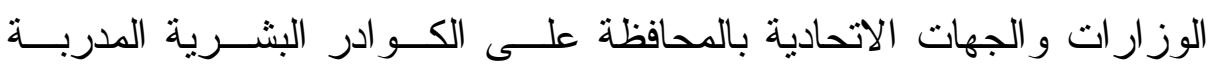
و المؤهلة من جهة ، وتدريب موظفيها وتطوير معارفهم ومهار اتهم وقــدر اتهم

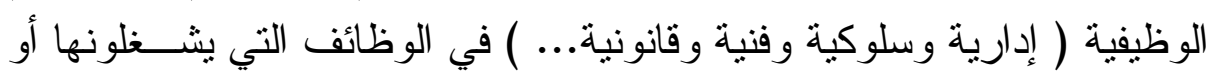


في الوظائف الأعلى المخطط لهم توليها في المستقبل ســـواء أكــان التــدريب

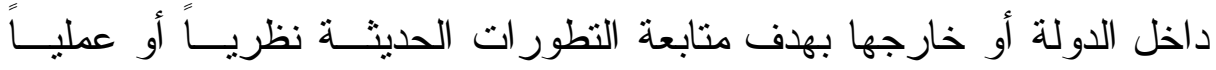

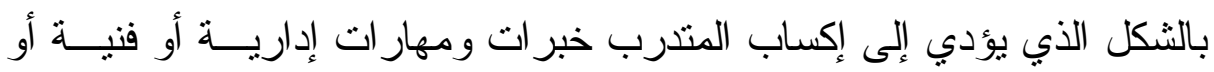

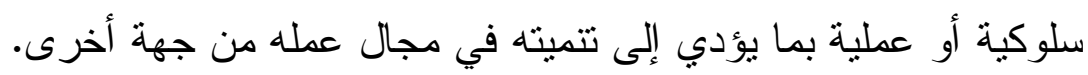

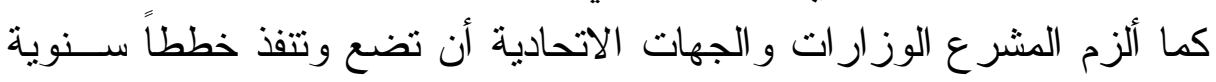

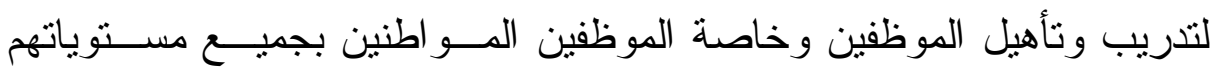

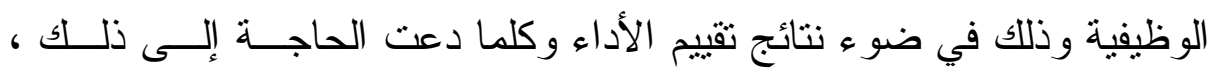

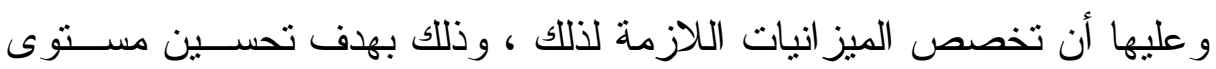

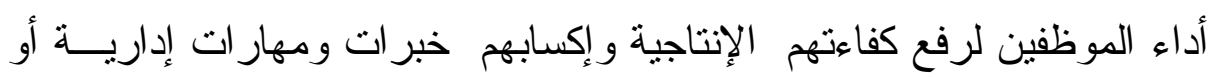

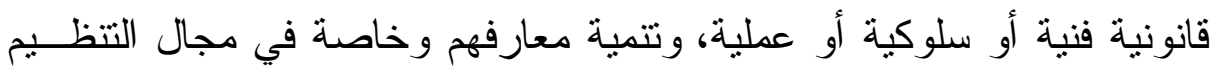

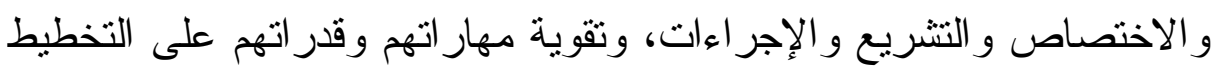

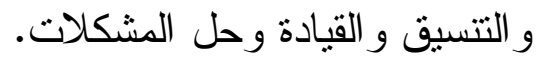
وبالنتيجة يجسد ويرسخ التدريب و التطوير و التأهيل في نطاق الوظيفة نوع من ون التئن

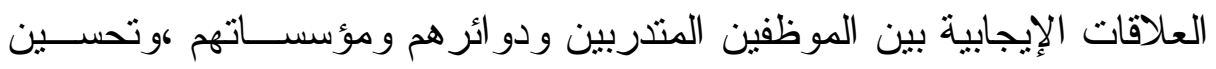

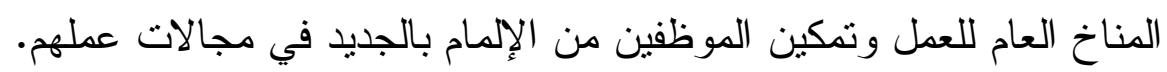

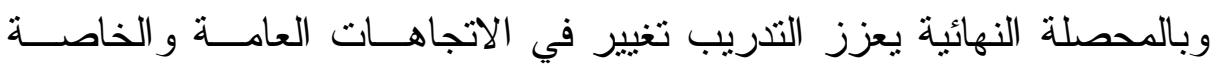
للموظفين من أجل تتمية وتطوير نماذج التفكير لديهم.

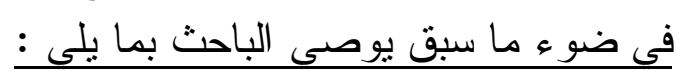

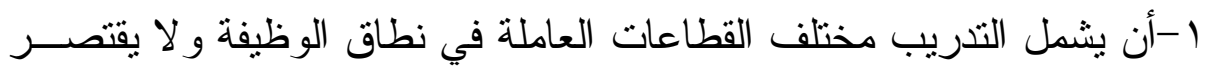

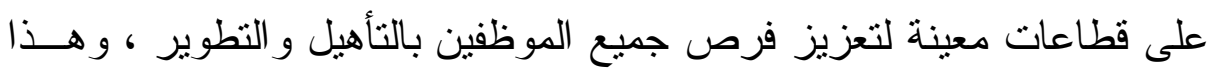

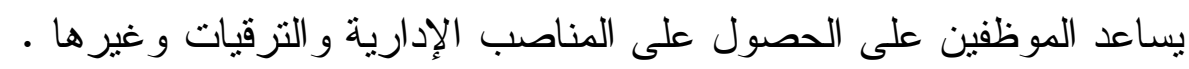

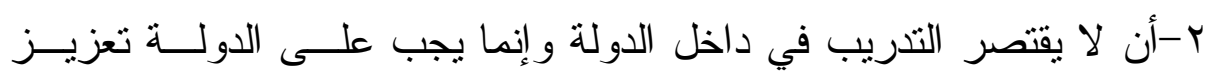
التدريب خار ج الدولة ، وخاصة في مجــالات العمليــات الإداريــة :القيــادة و التتظيم و التخطيط و التتسيق وحل المشكلات.

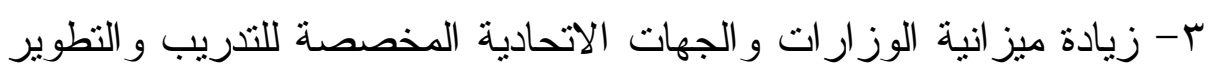

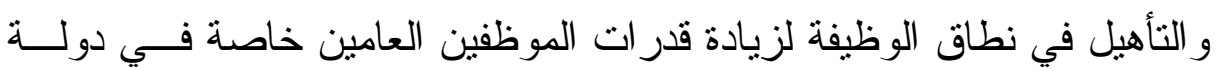

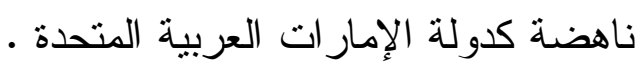

